\title{
Dentro II Convito di Erode di Filippo Lippi. Analisi geometrica e restituzione prospettica dello spazio dipinto
}

\author{
Barbara Ansaldi
}

Abstract

Il paper presenta i risultati dell'analisi dello spazio dipinto in prospettiva da Filippo Lippi per ospitare la sua interpretazione del Convito di Erode nel Duomo di Prato. Una volta individuato il riferimento prospettico, attraverso il procedimento inverso della prospettiva conica lineare sono state restituite le proiezioni ortogonali della pianta e delle sezioni dell'architettura rappresentata, a partire dalle quali si è potuto ricostruire il modello tridimensionale dell'apparato scenico in cui si svolgono, in un'unità spazio-temporale, i tre momenti della narrazione. Nonostante la sostanziale regolarità dell'impalcato prospettico, le operazioni di restituzione hanno evidenziato una serie di deroghe operate dall'artista a favore della valenza estetica e dell'armonia dell'immagine finale per l'osservatore ideale del quadro. La ricostruzione tridimensionale ottenuta, infine, è finalizzata alla realizzazione di un modello tattilmente esplorabile per la fruizione dello spazio dipinto da parte di utenti non vedenti.

Parole chiave

restituzione prospettica, Filippo Lippi, Convito di Erode, modellazione 3D, spazi dipinti.

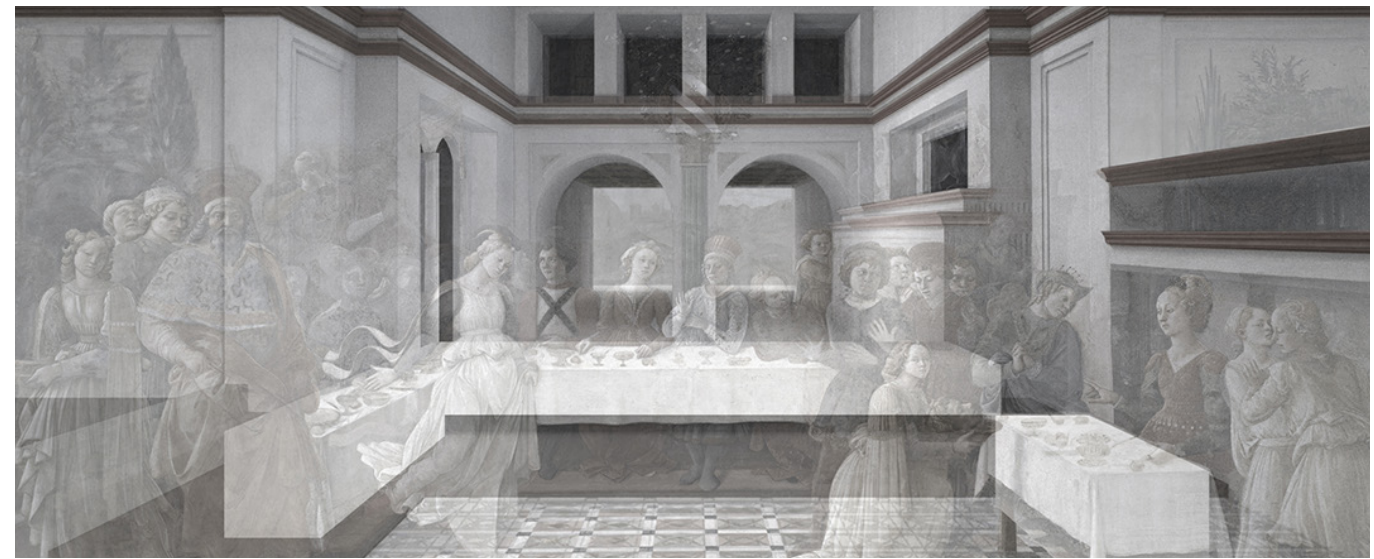




\section{Introduzione. II Convito di Erode di Filippo Lippi nel Duomo di Prato}

"Frate Filippo, agli occhi tuoi la Vita danza come colei davanti ad Erode, voluttuosa; e il tuo desio si gode d'ogni piacer quand'ella ti convita'

[Gabriele D'annunzio, Elettra, Le città del silenzio]

II tema del Banchetto di Erode è stato largamente interpretato nella storia dell'arte, mediante i più disparati medium artistici (fig. I). In epoca rinascimentale, l'episodio narrato dai Vangeli di Marco e Matteo si traduce in una rappresentazione vicina a quella tipica dei bozzetti teatrali, connotati dalla successione spaziale e temporale di più eventi che coesistono in un'unica scena. Nella versione quattrocentesca di Filippo Lippi (1406-1469), è possibile riscontrare una significativa influenza delle sacre rappresentazioni, molto probabilmente dovuta ai suoi legami con l'ordine dei Carmelitani [Holmes 1999], presso il cui monastero fiorentino crebbe e si formò. L'impatto delle sacre rappresentazioni sulla pittura di Lippi è evidente nel modo in cui i suoi lavori "danno l'impressione di essere 'messi in scena' [...] e i personaggi sono caratterizzati da grande coscienza di sé, da una forte consapevolezza della presenza di uno spettatore e del suo sguardo dall'esterno" [Holmes 1999, p. I67]. Come rileva anche Claudio Cerretelli, vice-direttore dell'Ufficio Beni Culturali di Prato," "caratteristici di fra Filippo sono l'abile vena narrativa che attualizza e rende comprensibili le complesse

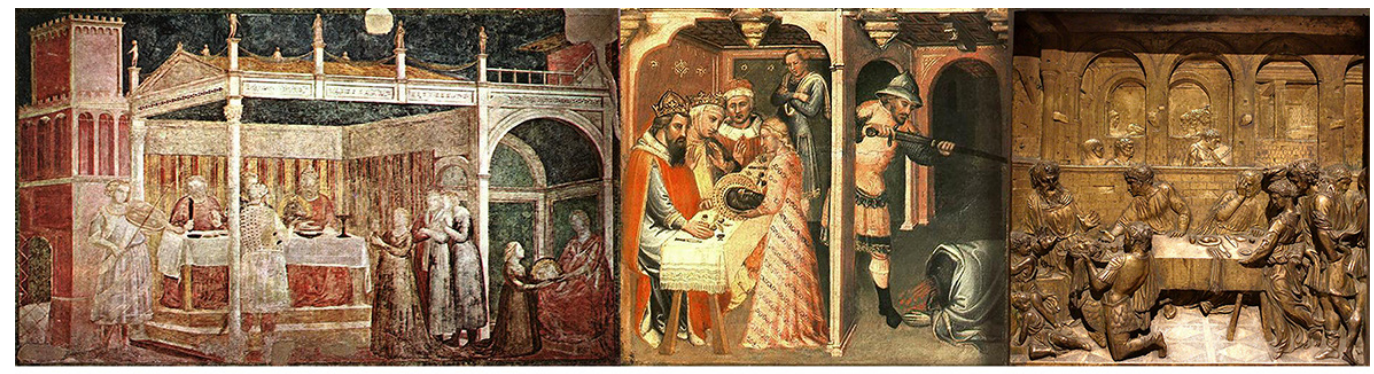

Fig. I. Da sinistra verso destra, dall'alto verso il basso: Giotto, I/ Banchetto di Erode, I320-1325, pittura a secco, Basilica di Santa Croce, Cappella Peruzzi, Firenze; Spinello Aretino, II Banchetto di Erode, 1385 , tempera su tavola, Szépmûvésze Múzeum, Budapest; Donatello, II Banchetto di Erode, 1423-27, rilievo in bronzo, Battistero di Siena; Masolino da Panicale, II Banchetto di Erode, 1435, affresco, Battistero di Castiglione Olona: Benozzo Gozzoli. Olona; Benozzo Gozzol, The Feast of Herod and the Beheading of Saint J 462 , tempera su tavola,
I the Baptist, National Gallery of Art, Washington; Domenico Ghirlandaio, The Feast of Herod, I 485- 1490 affresco, Cappella Tornabuoni, Santa Maria Novella, Firenze; Peter Paul Rubens, Banchetto di Erode, ca. 1635 38, olio su tela, National Galleries of Scotland, Edimburgo.
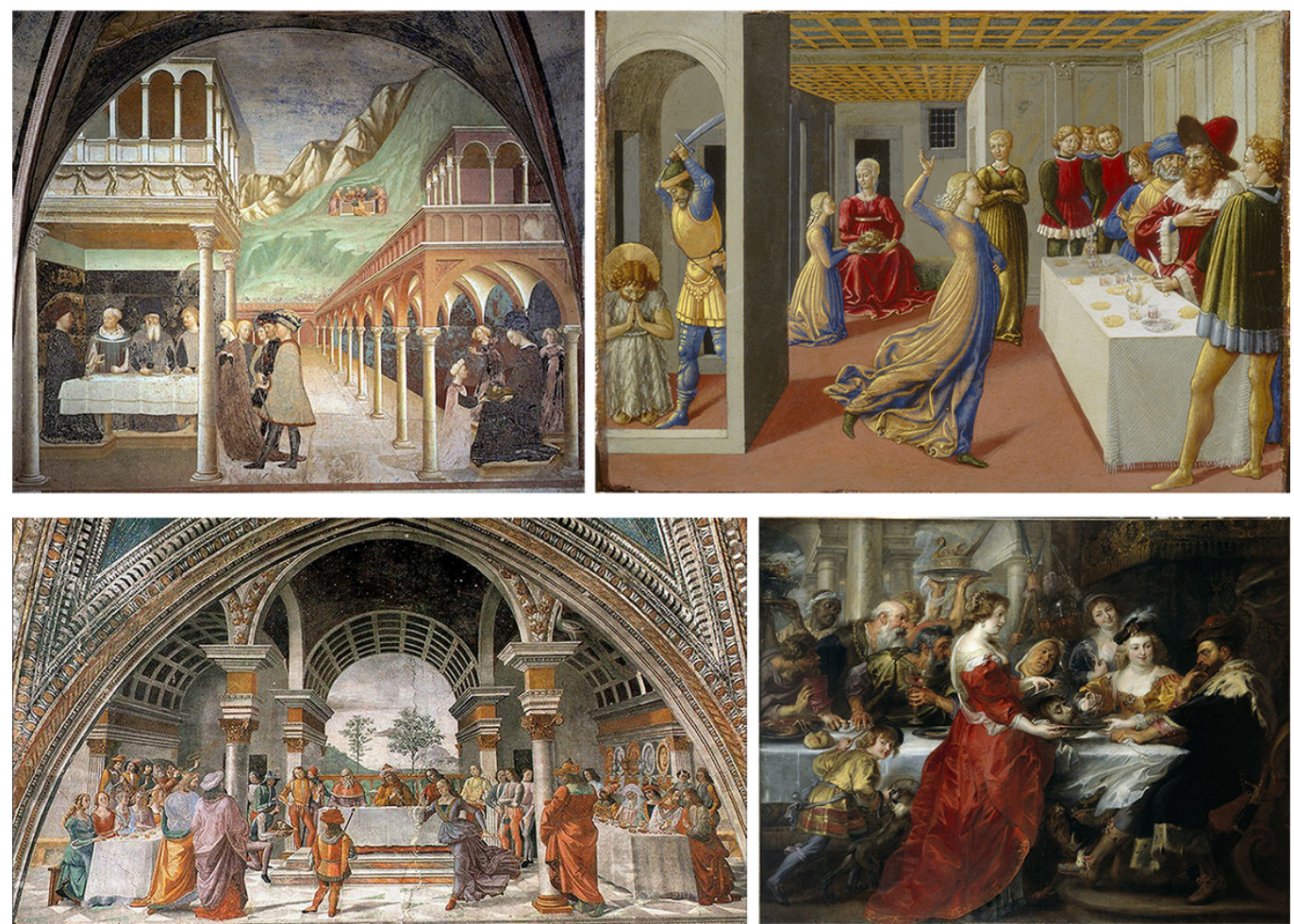
storie sacre, orchestrate come una grande rappresentazione teatrale" [Cerretelli 20 I 8]. II Convito di Erode (fig. 2) fa parte del noto ciclo di affreschi pratese in cui vengono narrate le Storie di santo Stefano e di san Giovanni Battista, che, secondo il Vasari, costituisce "la più eccellente di tutte le cose sue" [Vasari 20 I6, p. 4I I]. Fu eseguito dal Lippi insieme ai suoi collaboratori tra il 1452 e il 1465 , con lunghe pause derivanti da complesse vicende sentimentali dell'artista e da numerose altre commissioni. Il Convito di Erode rappresenta l'apice del complesso percorso compiuto dall'artista a Prato e a ragione è ritenuta l'ultima scena ad essere stata eseguita, pertanto è "la sola di cui è sicura la collocazione temporale, posta fra l'estate e l'autunno del I465" [Lapi Ballerini 20I4, p. 26].

Fig. 2. Filippo Lippi, Convito di Erode, dalle Storie di Giovanni Battista, I 452 1465, affresco, $450 \times$ $880 \mathrm{~cm}$. Prato, Duomo (Cappella Maggiore). Photo Credit: Fototeca Ufficio Beni Culturali Diocesi di Prato.

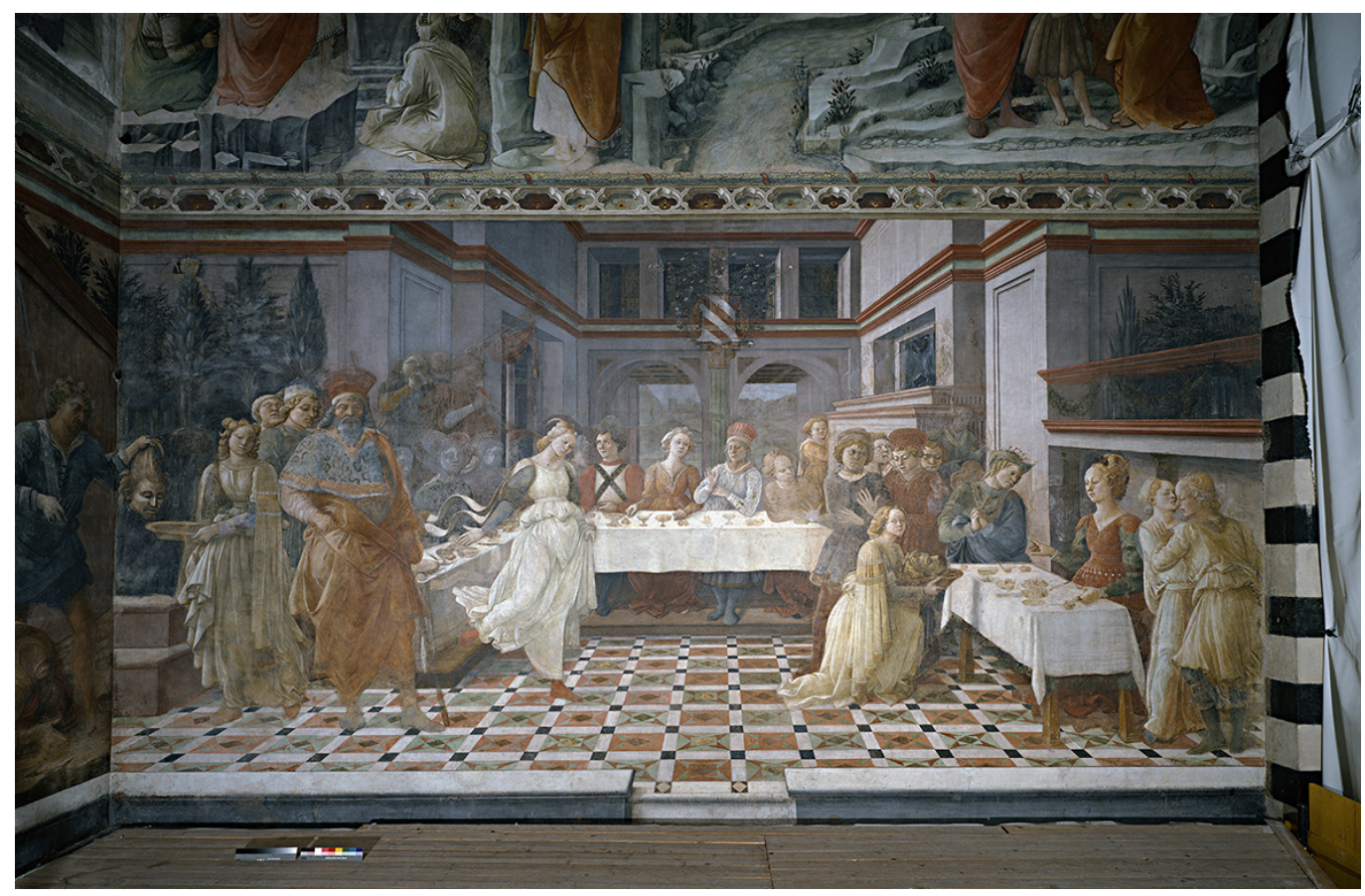

\section{Iconografia}

L'artista mette in scena un sontuoso banchetto in un elegante palazzo rinascimentale, popolato dai numerosi invitati in costumi della propria epoca. II tema è solo un pretesto per immaginare e descrivere nei particolari l'ampio spazio della sala, in cui il dramma degli eventi è solo intuito, quasi relegato ai margini della scena. Erodiade, in eleganti e aristocratiche vesti, è gelida e impassibile; il suo atteggiamento contrasta con la ricca gamma di espressioni di sorpresa, ribrezzo e disgusto dei convitati presenti alla macabra vicenda. La protagonista indiscussa è la figura sensuale e delicata di Salomè (probabilmente Lucrezia Buti, donna amata dal Lippi), definita da una linea di contorno sinuosa, sottile e morbida; la fanciulla compare ben tre volte e con tre volti diversi, avvolta in un abito leggero con i candidi veli svolazzanti nell'aria. Nella scena, come rileva A. Chrzanowska, "l'incontro tra innovazione e tradizione nella narrativa di Lippi è più che mai visibile. Qui, più che nel resto del ciclo, il contrasto tra uno spazio prospettico coerente e la narrazione continua è amplificato" [Chrzanowska 20 I6, p. 205]. L'affresco è composto dai tre momenti più importanti dell'episodio biblico: a sinistra la Decollazione di Giovanni Battista (il boia e il corpo decapitato del Battista sono situati sulla parete adiacente all'affresco), al centro la Danza di Salomè e a destra la Presentazione della testa ad Erodiade (fig. 3). Gli eventi narrati, seppur temporalmente ben distinti, sono unificati in uno spazio omogeneo grazie al rigoroso impianto prospettico tracciato 
Fig. 3. Nelle immagini sono evidenziati, in ordine cronologico, i tre moment della narrazione. Dall'alto verso il basso: la Danza di Salomé, la Decollazione di San Giovanni Battista e la Presentazione della Testa a Erodiade. dalle piastrelle di marmo intarsiato dal pavimento, dalle tavole coperte da bianche tovaglie e dallo scorcio delle pareti, il cui punto di vista principale è posto sull'asse di simmetria verticale (fig. 4). L'ordine di lettura dei momenti rappresentati non è lineare; il racconto parte dallo spazio circoscritto dai tavoli al centro (la danza), per poi spostarsi a sinistra (la decapitazione) e concludersi a destra (la consegna della testa ad Erodiade). Salomé si muove su piani prospettici diversi, ma con un andamento quasi rettilineo (fig. 5). In questo

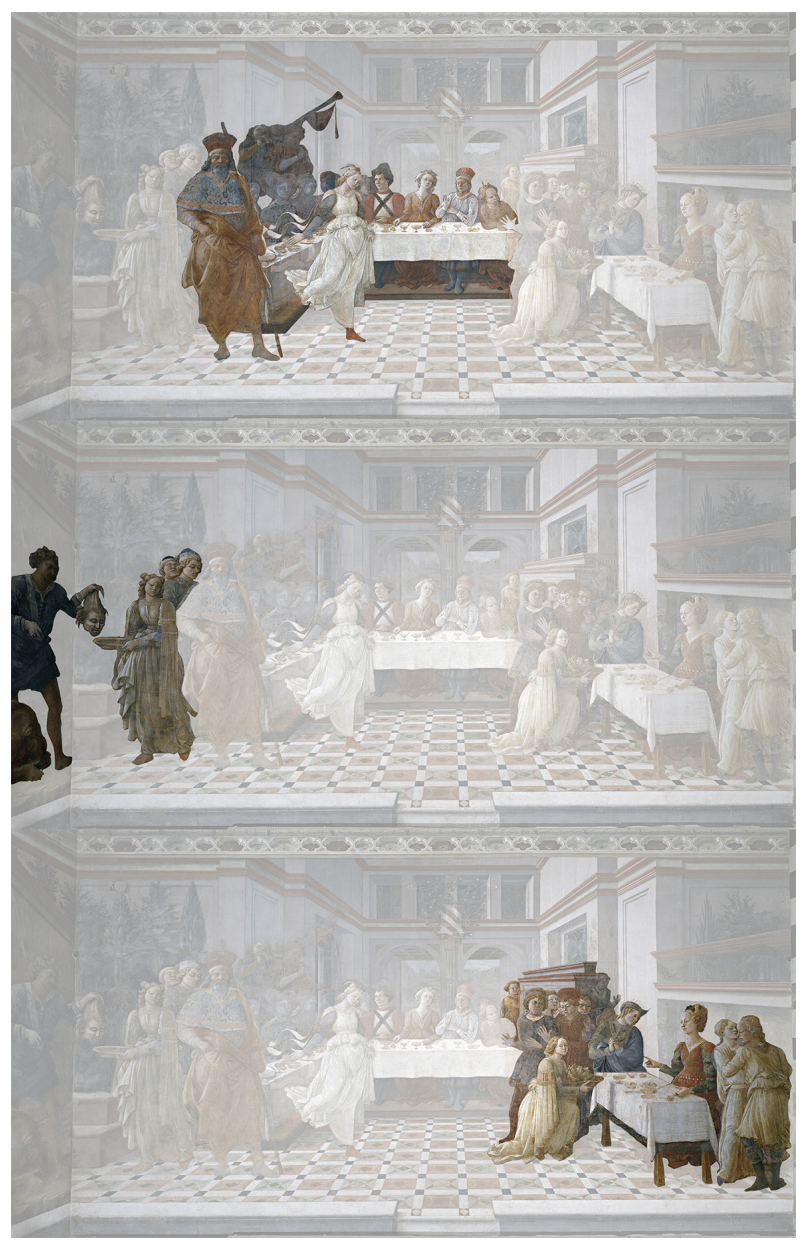

movimento, la Salomé della scena centrale sembra voler tracciare una linea temporale scandita dal ritmo dei suoi spostamenti, come se danzasse da sinistra verso destra, mettendo in relazione spaziale le tre fasi della narrazione in ordine non cronologico. Tuttavia, la scena a sinistra è posta più in disparte rispetto alle altre, come se si volesse isolare il momento più tragico della storia, la Decollazione. Nonostante la coesistenza di tre diversi momenti nella stessa scena, Lippi riesce a preservare la leggibilità della sequenza grazie al gioco di sguardi dei personaggi che interagiscono - in maniera più o meno diretta - con l'osservatore, guidandolo nella narrazione. Si noti, ad esempio, la figura di Salomè inginocchiata che rivolge lo sguardo allo spettatore o l'ultimo commensale della tavolata parallela al quadro, il quale si volta verso la sua sinistra, come se si accorgesse dello svolgimento della scena successiva a quella di cui fa parte. A marcare la separazione tra le scene sono perlopiù i personaggi posti su piani prospettici diversi, come il personaggio con il copricapo e la barba in primo piano a sinistra - il mazziere - e il gruppo di commensali attorno al tavolo sulla destra. È proprio lo sforzo di Lippi nell'unificare l'organizzazione spaziale delle scene a trasformare l'affresco in una performance, rendendo possibile "l'animarsi delle figure nell'immaginazione 


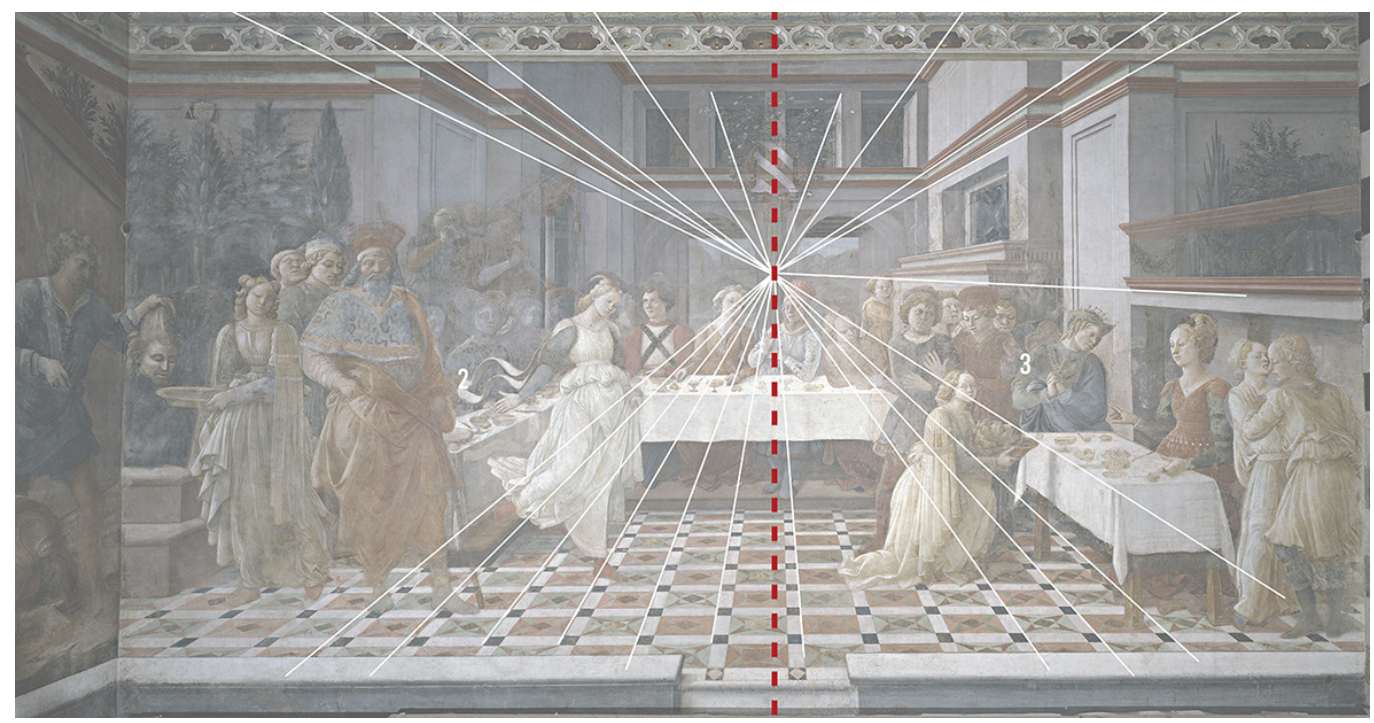

Fig. 5. I diversi livelli prospettici della scena pittorica e movimento ideale di Salomé.
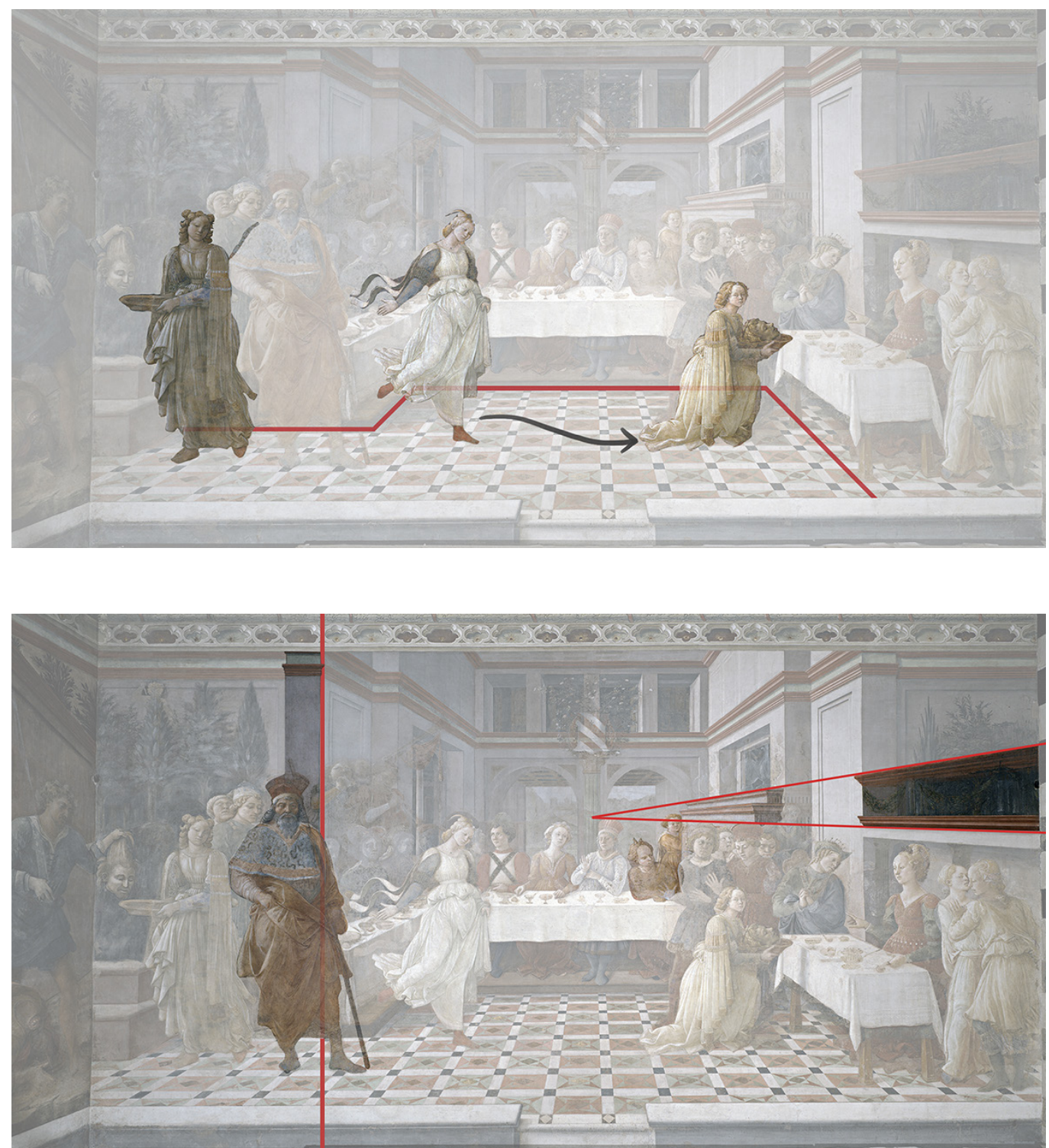

di una nuova scena. 
dello spettatore" [Chrzanowska 20 I6, p. 207]. Non sono, però, solo i personaggi a dividere i momenti del racconto: analizzando più attentamente l'impianto architettonico, si può notare come le due scene laterali sono più vicine allo spettatore rispetto a quella centrale, più arretrata. Infine, la presenza di una lesena sul lato sinistro definisce, insieme all'imponente figura fuori scala del mazziere, il limite della scena in cui la testa del Battista è consegnata a Salomè, mentre sul lato opposto le cornici orizzontali spezzano la simmetria dell'impianto architettonico, inquadrando la terza ed ultima scena (fig. 6).
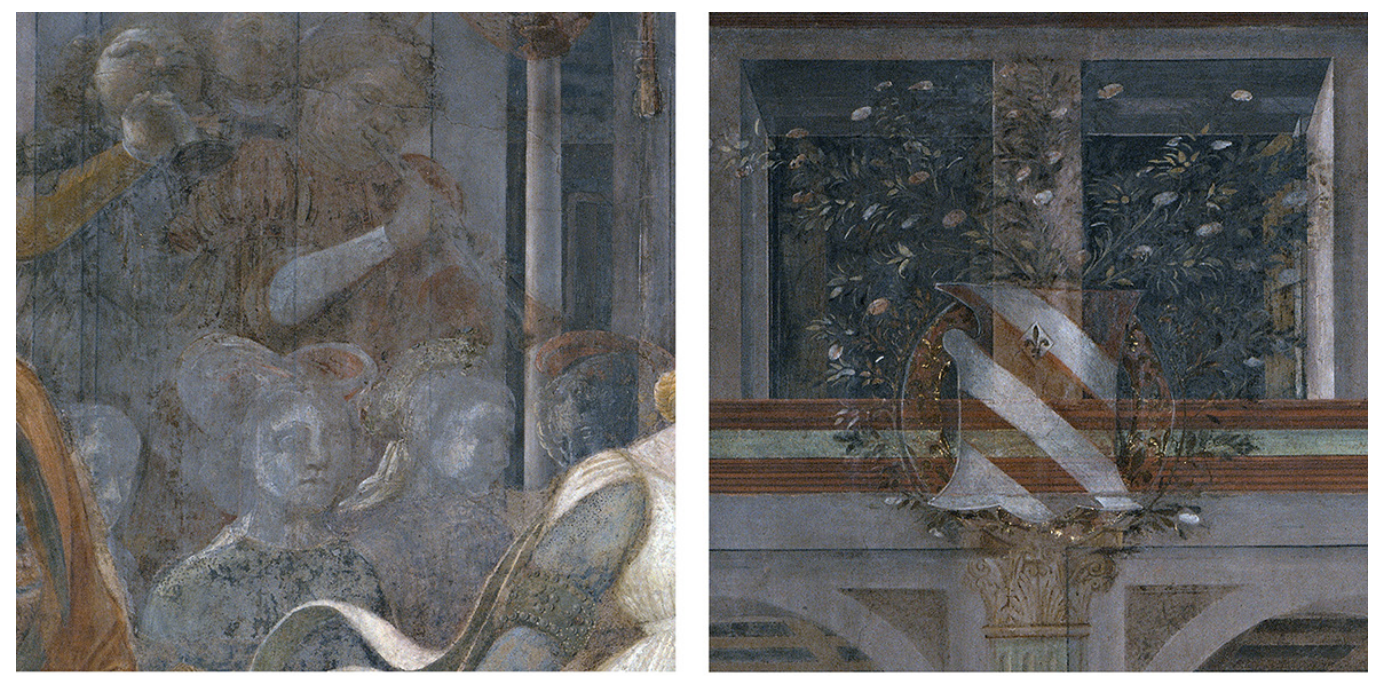

Fig. 7. Personaggi, dettagli e oggetti 'evanescenti' perché aggiunti a secco perche aggiunti a secco
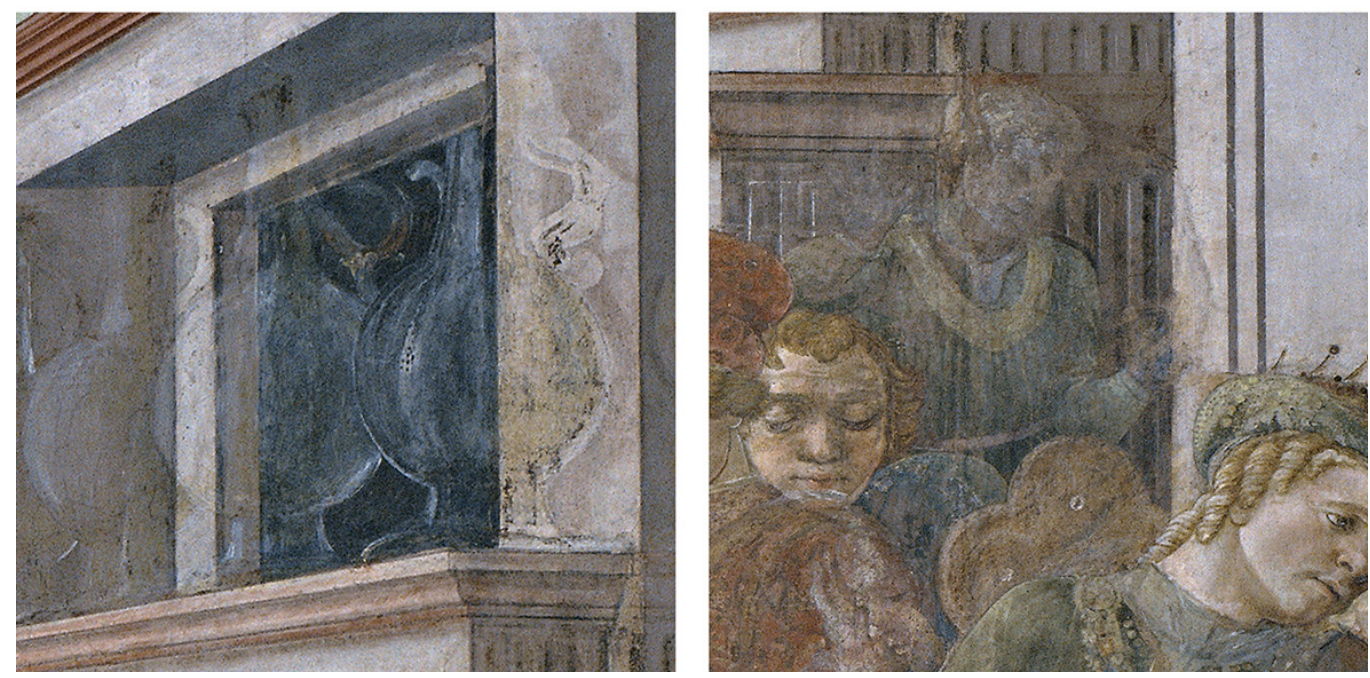

\section{Restituzione prospettica dello spazio dipinto}

La restituzione dello spazio dipinto da Filippo Lippi in prospettiva centrale è stata condotta mediante il procedimento inverso della prospettiva lineare conica, che ha reso necessario individuare dapprima l'orientazione interna del riferimento a partire dal punto principale $\mathrm{V}_{0}$, proiezione ortogonale sul quadro (piano dell'affresco) del punto di vista dell'osservatore $V$. La linea d'orizzonte è stata individuata come luogo dei punti di intersezione delle rette orizzontali perpendicolari al quadro. Il punto $\mathrm{V}_{0}$ appartiene alla retta di orizzonte, trattandosi di una prospettiva a quadro verticale, ed è il centro del cerchio di distanza che ha come raggio $\bigvee_{0} \bigvee^{*}$, dove $\bigvee^{*}$ corrisponde al punto di vista $\bigvee$ ribaltato sul quadro [Pagliano 2005, p. 42]. La retta fondamentale $\mathrm{f}$, in questo caso fittizia, è stata posta coincidente con il limite inferiore 
del dipinto come da consuetudine diffusa nel caso di restituzione prospettica di architetture dipinte a quadro verticale. II ridisegno delle rette prospettiche del pavimento, nonostante un'apparente coerenza e regolarità dell'impianto, mette in luce una mancata convergenza verso un'unica coppia di punti di distanza delle diagonali dei quadrilateri separati da fasce bianche, che il pittore lascia intendere chiaramente che siano di forma quadrata. Pertanto, sono stati presi come riferimento per l'individuazione dei punti $D_{1}$ e $D_{2}$ le mattonelle (supposte di forma quadrata) della seconda e terza fila (parallele al quadro prospettico) verso l'osservatore, le cui diagonali, se prolungate fino alla linea d'orizzonte, individuano una nuvola di punti d'intersezione, i quali differiscono di poco e solo a causa di alcune inevitabili imprecisioni esecutive nel dipinto, specialmente considerando la grande scala dell'affresco. I punti di distanza, dunque, sono stati fissati nel centro dell'area risultante dalle suddette intersezioni sulla linea d'orizzonte. Una volta identificato il riferimento prospettico dell'immagine dipinta, si è proceduto all'analisi geometrica e alla restituzione grafica di pianta e sezioni dello spazio dipinto mediante il metodo del ribaltamento applicato alla prospettiva a quadro verticale. L'analisi geometrica dimostra che lo spazio di Lippi è caratterizzato da un impianto sostanzialmente regolare (tutte le rette orizzontali hanno fuga nello stesso punto, tranne qual-

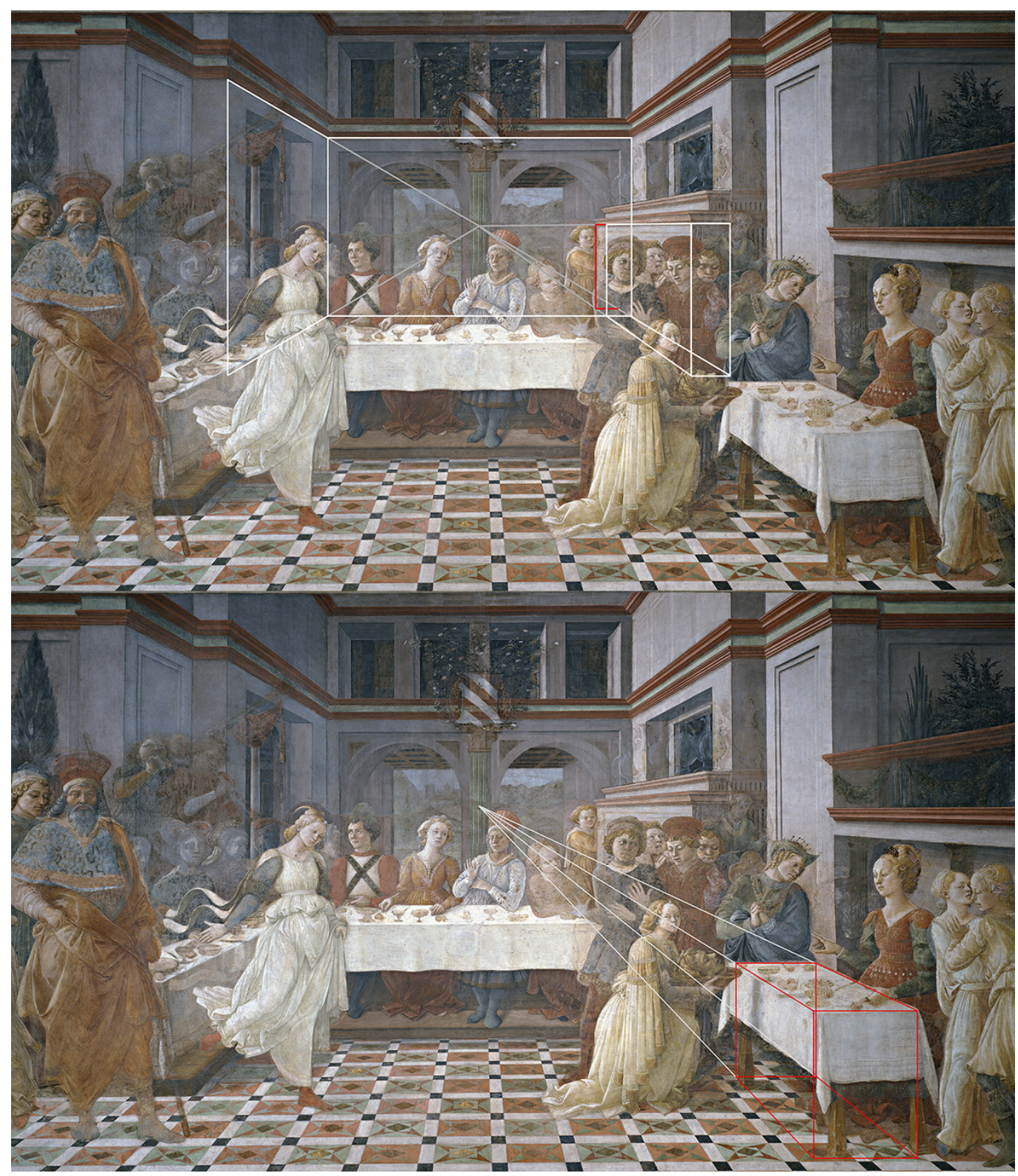


che isolata eccezione). È evidente la volontà di mettere in scena uno spazio basato su un progetto architettonico ben studiato, caratterizzato da una forte simmetria lungo l'asse verticale passante per il punto $V_{0}$ (owero la traccia-fuga del piano visuale principale) e apparentemente bilanciato e proporzionato. L'ipotesi che lo spazio di Lippi sia dichiaratamente simmetrico viene confermata dalla pianta restituita in base al riferimento fissato, che è quasi perfettamente simmetrica rispetto al suo asse longitudinale, nonostante le imprecisioni dovute all'esecuzione pittorica. Ad esempio, le aperture laterali sono speculari e della medesima lunghezza, così come gli archi a tutto sesto e le finestre sul fondo, che risultano simmetrici rispetto alla parasta centrale (sulla quale, non a caso, è collocato anche il punto di fuga).Tuttavia, lo spazio dipinto da Lippi non è scevro da irregolarità, sia dovute alla difficoltà esecutiva, sia a una serie di deroghe operate dall'artista per assecondare scelte puramente estetiche, finalizzate a migliorare il rapporto visivo tra l'architettura e le figure umane. Lippi, quindi, sacrifica il rigore formale dell'architettura dipinta a favore della visione complessiva. Inoltre, è chiaramente visibile come alcuni personaggi e dettagli decorativi siano stati aggiunti in un successivo momento, mediante tecnica 'a secco' [Gittins, Vedovello 20 I4, p. 54] [I]: alcune parti hanno, infatti, subito un processo di deterioramento maggiore e più rapido rispetto alle parti affrescate, come il gruppo di personaggi addossati alla parete sinistra della scena, dietro il tavolo, che oggi appaiono come 'spettri' trasparenti, sbiaditi ed evanescenti rispetto alla marcata opacità delle altre figure umane presenti nel dipinto [Lapi Ballerini 20 I4, p. 26] [2], o, ancora, lo stemma del Ceppo Nuovo di Francesco di Marco Datini circondato dai gigli, simbolo del Comune di Prato [Borsook 1975, p. 57] (fig. 7).

L'analisi prospettica ha inoltre rivelato che l'elemento architettonico coronato da modanature, collocato davanti all'apertura lungo la parete destra della scena (nella quale risulta essere inglobato), viene dipinto in posizione arretrata rispetto a quella coerente con i riferimenti prospettici fissati e che risulterebbe se il metodo prospettico venisse applicato rigorosamente (fig. 8a). L'elemento architettonico, così impropriamente rappresentato da Lippi, andrebbe a intersecare la parete di fondo e non sarebbe visibile. Anche il tavolo a cui siede Erodiade non è una rappresentazione prospettica del tutto coerente: tracciandone la sagoma, infatti, si scopre che la sua geometria non è riconducibile a quella del parallelepipedo in cui dovrebbe risultare inglobato (fig. 8b). Dalla restituzione è possibile notare come lo spazio rappresentato da Lippi risulti correttamente progettato nella parte anteriore alla lunga tavola imbandita, dominata dalla scacchiera colorata del pavimento a motivi geometrici e nel quale si muove il personaggio principale, Salomé: è il luogo della danza e dei movimenti scenici della protagonista.Tale spazio e gli elementi al suo presentano proporzioni e

Fig. 9. Motivo geometrico caratterizzante i quadranti del pavimento, nei due diversi schemi di colori
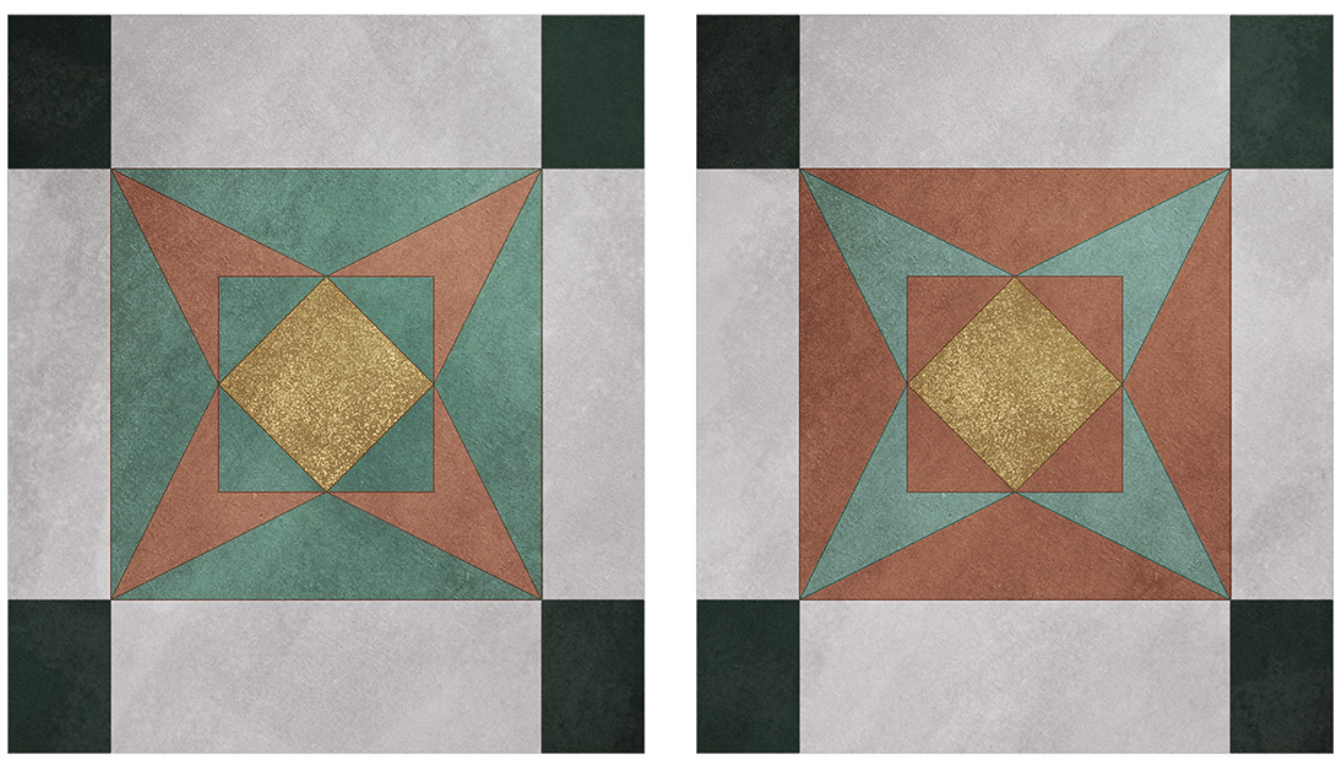
dimensioni credibili, al contrario di ciò che avviene a partire dalla porzione del tavolo disposto parallelamente al quadro, che è risultato avere una profondità doppia rispetto al braccio laterale e che, di conseguenza, condiziona un'improbabile rappresentazione dei commensali. Questi ultimi appaiono seduti su una panca, secondo quanto intermittentemente visibile tra le gambe e le vesti dei personaggi; si tratta, tuttavia, di una posizione anatomicamente impossibile data la notevole profondità del tavolo che porta a una correzione della forma e della posizione delle gambe che si adattano in maniera poco credibile agli arredi dipinti della scena, piuttosto che mantenere una coerente forma anatomica. La scelta del Lippi di assegnare alla tavola una profondità maggiorata è probabilmente finalizzata a rendere meglio visibili gli oggetti presenti sul piano orizzontale. Procedendo verso il fondo del dipinto, gli ambienti restituiti si allungano considerevolmente, in particolare al di là dei due archi a tutto sesto della parete retrostante al banchetto. Nell'apertura rettangolare della parete sinistra è visibile una coppia di archi sorretti al centro da una colonna; tali archi, pur suggerendo la forma a tutto sesto, sono in realtà a sesto molto ribassato e lo spessore della parete che li contiene in realtà è troppo esiguo per ospitare la colonna centrale. È forse per

Fig. I0. Dall'alto verso il basso, da sinistra verso destra: Filippo Lippi, I funerali di santo Stefano, ca. I460, ciclo di affreschi con le Storie di santo Stefano e san Giovanni Battista, Duomo, Prato; Filippo Lippi, Circoncision ca. | 460-1465, tavola, Chiesa dello Spirito Santo, Prato. A destra: Filippo Lippi, Santo Stefano è nato e sostituito con un altro bambino (particolare) ca. I 460, ciclo di affreschi con le Storie di santo Stefano e san Ganto Battista, Duomo, Prato.

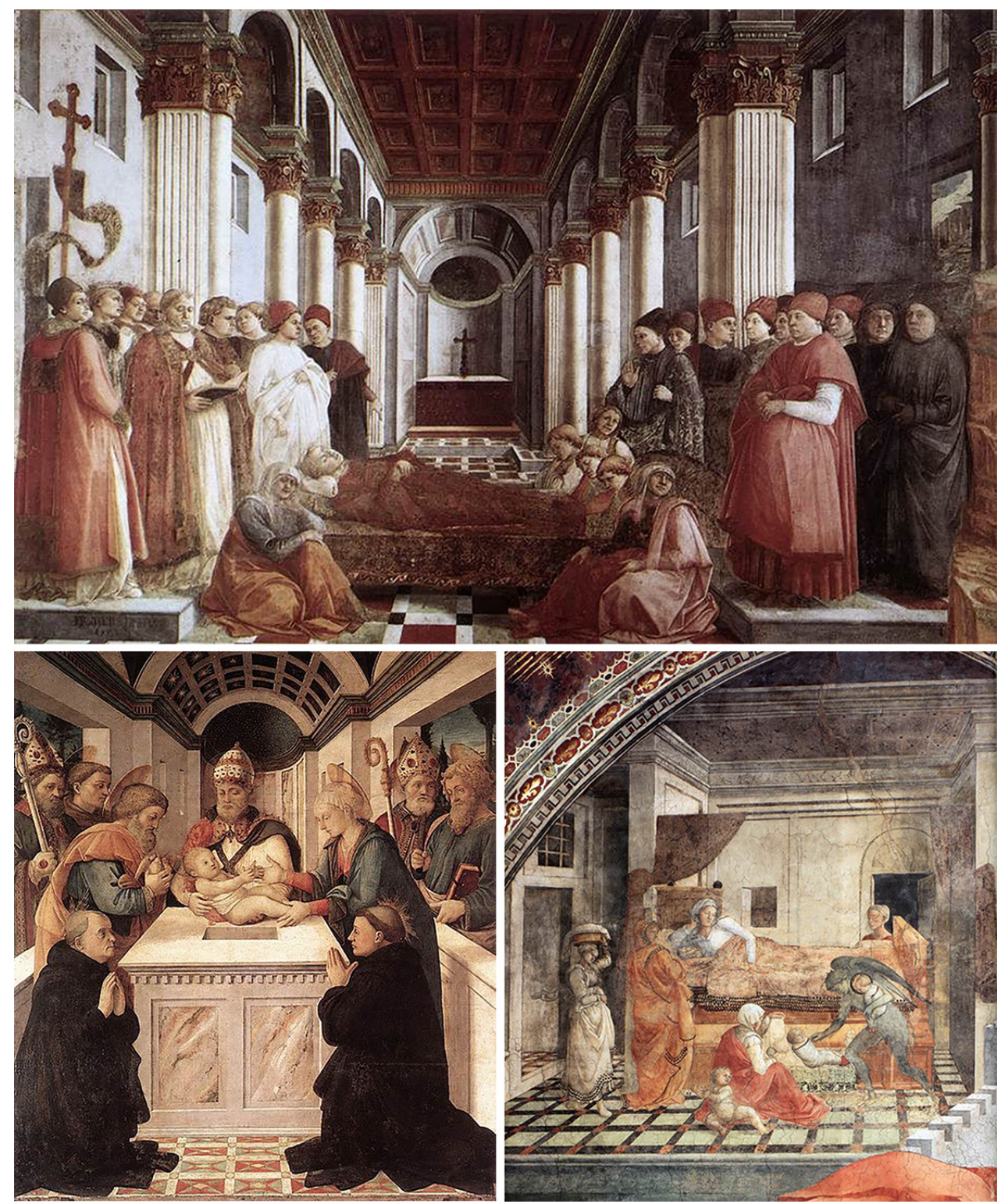


mascherare queste incertezze che il pittore ha sovrapposto in un secondo momento lo stendardo della tromba suonata dal personaggio proprio in corrispondenza del capitello della colonna che corrisponde all'imposta degli archi. II cassettonato del soffitto visibile al di là degli archi è composto da elementi rettangolari divisi da fasce di notevole ampiezza. Lippi ottiene volutamente un effetto di prospettiva rallentata per far sì che le divisioni tra i cassettoni siano ben visibili e non si riducano eccessivamente lungo la profondità dello spazio. Nella restituzione prospettica, per ripristinare la coerenza dell'unità spaziale, sono state operate delle piccole correzioni laddove l'immagine prospettica non risultava perfettamente coerente con il riferimento. In particolare, la restituzione del pavimento geometrico conferma le incongruenze già evidenziate, rivelando che i quadranti non sono tutti perfettamente quadrati e che tendono a 'schiacciarsi' progressivamente verso il fondo, così come accade per le fasce orizzontali che li separano. Le divisioni verticali, invece, presentano una maggiore regolarità e la loro ampiezza differisce minimamente da fascia a fascia. Per regolarizzare l'impianto architettonico degli spazi prospettici restituiti, nella restituzione filologica si è deciso di rendere perfettamente quadrati tutti i quadranti del pavimento e di ampiezza costante

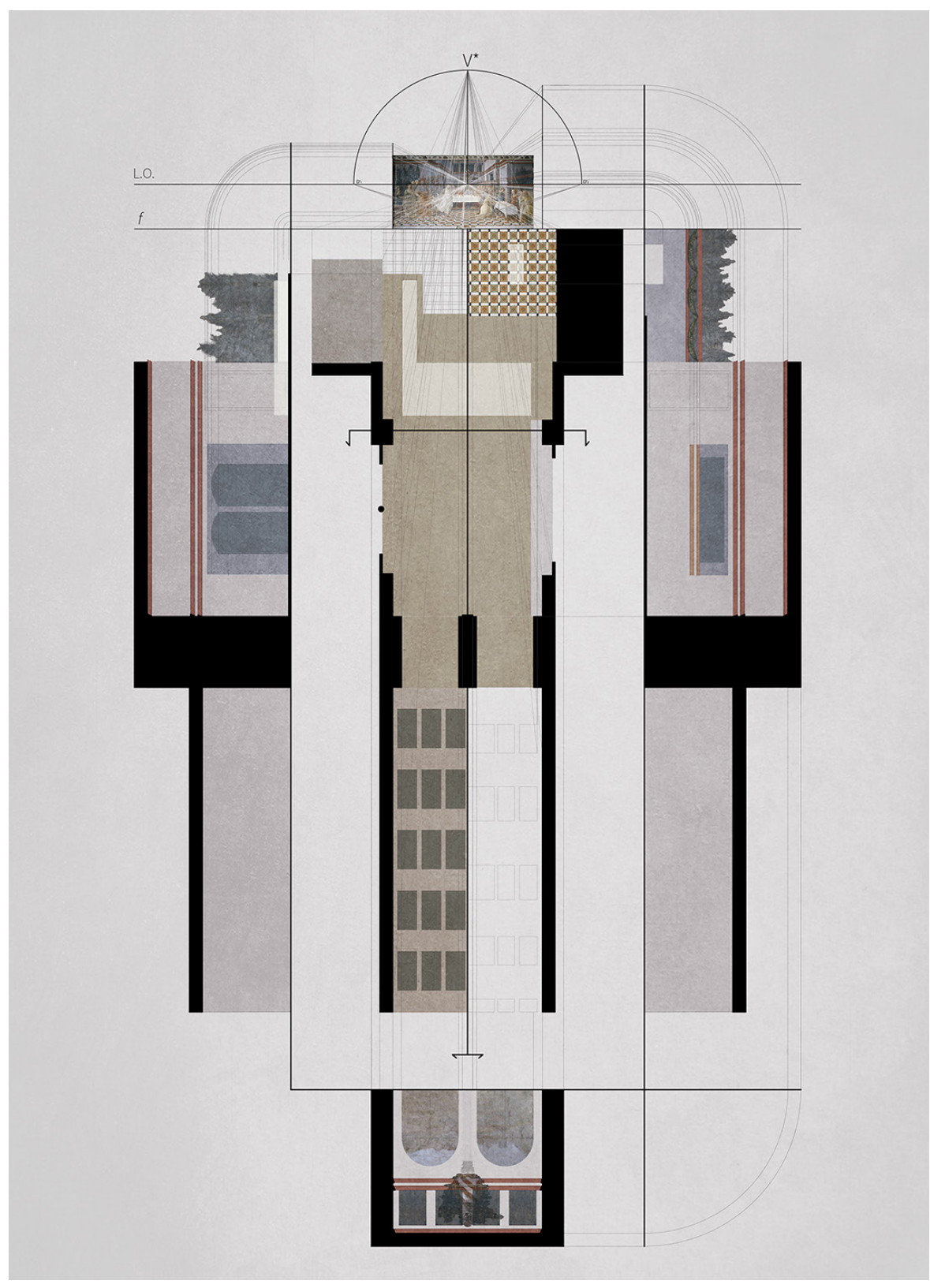


le fasce che li separano, lasciando invariato il numero di file parallele e perpendicolari al quadro. II motivo geometrico con il quale sono decorati i quadranti risultano così composti da un quadrato centrale (originariamente in cera dorata), da un rombo equilatero in esso inscritto e da quattro triangoli isosceli aventi ognuno base coincidente con uno dei lati del rombo e vertice in uno dei quattro vertici del quadrante (fig. 9). Analogamente, sono stati regolarizzati i cassettoni del soffitto dell'ambiente collocato oltre gli archi a tutto sesto, rispettando le proporzioni delle fasce che separano orizzontalmente gli elementi rettangolari e lasciando invariato il numero delle file parallele e perpendicolari al quadro. Le ipotesi formulate sulla pavimentazione quadrata e sul tipo rettangolare di cassettonato ligneo sono state condotte anche in base all'osservazione di altre opere del Lippi, nelle quali ricorrono analoghe tipologie (fig. I0). L'impianto acquista così regolarità, rispettando al contempo le volontà dell'artista. II modello digitale ottenuto a partire dai grafici della restituzione può essere stampato in 3D e collocato accanto all'affresco originale per una fruizione da parte di un pubblico non vedente e per una migliore comprensione dello spazio messo in scena a beneficio di tutti i visitatori.

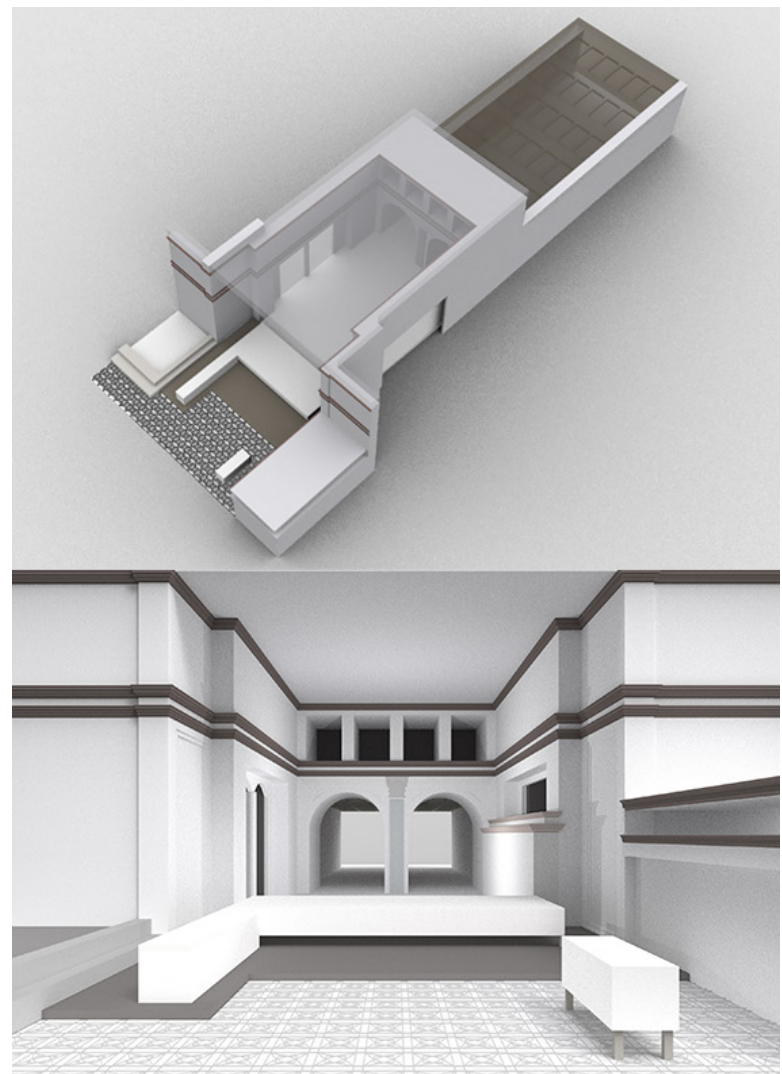
grafica dell'autrice).

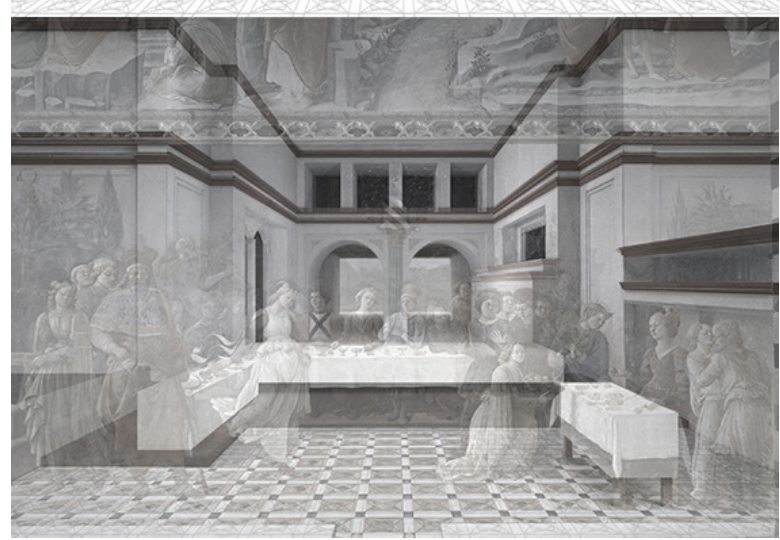




\section{Conclusioni}

Le operazioni di restituzione prospettica hanno messo in luce le scelte effettuate da Filippo Lippi nel progettare lo spazio destinato ad accogliere la rappresentazione degli eventi narrati, connotato da una globale armonia percettiva e una sostanziale regolarità fondata sulla simmetria, interrotta solo laddove l'architettura viene chiamata a soddisfare urgenze narrative. La restituzione prospettica, dunque, ancora una volta si dimostra essere tutt'altro che una sterile operazione di traduzione automatica dall'immagine in prospettiva di uno spazio alle sue piante, prospetti e sezioni: è, al contrario, un atto interpretativo vero e proprio. L'azione critica della restituzione filologica è fondamentale quando si trattano gli spazi dipinti, prodotti dall'immaginario di un'artista che, nel suo agire tra norma e deroga, spesso e volentieri pone esigenze percettive ed estetiche davanti alla corretta applicazione del metodo scientifico. L'interpretazione dell'immagine dipinta tiene insieme competenze di geometria descrittiva, storia dell'arte e della rappresentazione e disegno digitale, che in essa appaiono

\section{Note}

[I] Come rilevano Gittins e Vedovello, "nel Convito di Erode si nota una conduzione più libera e il ricorso alla pittura 'a secco' è più esteso. Nella zona centrale, ad esempio, le giornate seguono l'architettura e la decisione di sistemare lì un gruppo di persone - non è dato sapere se già previsto in partenza o aggiunto per calibrare la composizione - viene risolta senza stendere nuovo intonaco, ma dipingendo tranquillamente tutto 'a secco"' [Gittins, Vedovello 20 I4, p. 54].

[2] Come rileva Isabella Lapi Ballerini, "ben I 3 figure, oggi evanescenti se non quasi invisibili, intervengono a secco per affollare la composizione, di cui 7 in un sol gruppo fra Salomè danzante e il mazziere; aggiunte, e non 'soppresse'" [Lapi Ballerini 20 | 4, p. 26].

\section{Riferimenti bibliografici}

Borsook Eve (1975). Fra Filippo Lippi and the Murals for Prato Cathedral. In Mitteilungen des Kunsthistorischen Institutes in Florenz, 19, pp. I- |48, I/1975.

Cerretelli Claudio (2018). Personaggi importani: Filippo Lippi: <hhttp://www2.po-net.prato.it/artestoria/personalita/filippolippi/pagina87.html>.

Chrzanowska Agata (2016). Narrative Fresco and Ritual: Filippo Lippi, Domenico Ghirlandaio and Performative Properties of the Religious Art in Quattrocento Florence. Durham: Durham University

Gittins Mark, Vedovello Sabrina (20/4). Problemi operativi e risultati del recente restauro. In Benassai Paolo, Ciatti Marco, De Marchi Andrea et al. (a cura di). Officina Pratese: tecnica, stile, storia. Firenze: Edifir Edizioni Firenze, pp. 53-62.

Holmes Megan (1999). Fra Filippo Lippi. The Carmelite Painter. New Haven:Yale University Press.

Kubovy Michael (1992). La freccia nell'occhio. Psicologia della prospettiva e arte rinascimentale. Padova: Franco Muzzio Editore.

Lapi Ballerini Isabella (20|4). II restauro degli affreschi di Filippo Lippi a Prato fra metodo e riflessione critica. In Benassai Paolo, Ciatti Marco, De Marchi Andrea et al. (a cura di). Officina Pratese: tecnica, stile, storia. Firenze: Edifir Edizioni Firenze, 19-30.

Pagliano Alessandra (a cura di). (2005). La scena svelata: architettura, prospettiva e spazio scenico. Padova: II Poligrafo.

Paolucci Antonio (2007). Filippo Lippi. Firenze: Giunti.

Ruda Jeffrey (1993). Fra Filippo Lippi. Life and Work with a Complete Catalogue. London: Phaidon.

Vasari Giorgio (20 I 6). Le vite dei più eccellenti pittori, scultori e architetti. Roma: Newton Compton Editori. (Ed originale I 550).

Autore

Barbara Ansaldi, Università degli Studi di Napoli "Federico II", barbara.ansaldi@unina.it

Per citare questo capitolo: Ansaldi Barbara (2020). Dentro II Convito di Erode di Filippo Lippi. Analisi geometrica e restituzione prospettica dello spazio dipinto/Inside The Feast of Herod by Filippo Lippi. Geometric analysis and perspective restitution of the painted space. In Arena A., Arena M., Brandolino R.G., Colistra D., Ginex G., Mediati D., Nucifora S., Raffa P. (a cura di). Connettere. Un disegno per annodare e tessere. Atti del $42^{\circ}$ Convegno Internazionale dei Docenti delle Discipline della Rappresentazione/Connecting. Drawing for weaving relationships. Proceedings of the 42 th International Conference of Representation Disciplines Teachers. Milano: FrancoAngeli, pp. 2907-2930. 


\section{Inside The Feast of Herod by Filippo Lippi. Geometric Analysis and Perspective Restitution of the Painted Space}

Barbara Ansaldi

\section{Abstract}

The paper presents the results of the analysis of the perspective-based space painted by Filippo Lippi in order to accommodate his rendition of the Feast of Herod in the Duomo of Prato. Once the perspective's coordinates have been identified, the orthogonal projections of the plan and sections of the painted architecture were obtained through geometric restitution of perspective. Starting from them, it was possible to build a digital three-dimensional model of the scenic setting where the three main events of the narration take place in a space-time unity. Despite the substantial regularity of the perspective layout, the results of the restitution showed that the artist made a series of deviations from the rules of perspective in favor of the overall aesthetic value and harmony of the final image so that the ideal viewer could fully appreciate it. Finally, the digital three-dimensional model be 3D printed in order to provide a tactile model that can be experienced through touch, allowing the fruition of the painted space by blind users.

Keywords

perspective restitution, Filippo Lippi, Feast of Herod, 3D modeling.

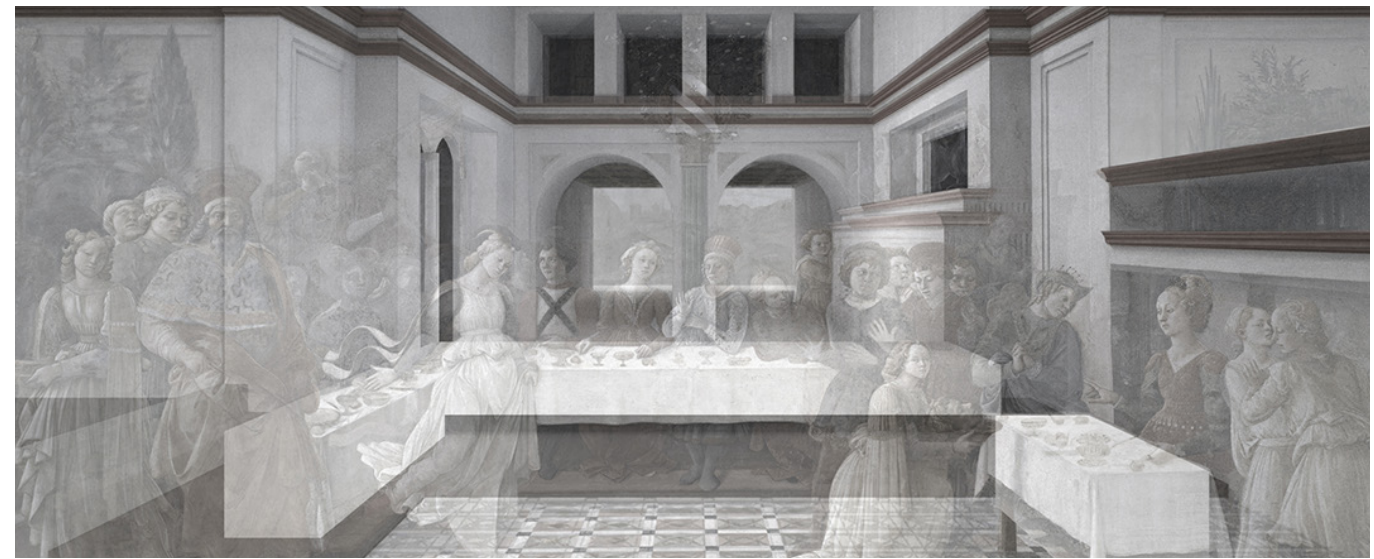




\section{Introduction. The Feast of Herod by Filippo Lippi in the Duomo of Prato}

"Frate Filippo, agli occhi tuoi la Vita danza come colei davanti ad Erode,

voluttuosa; e il tuo desio si gode

d'ogni piacer quand'ella ti convita'

[Gabriele D'Annunzio, Elettra, Le città del silenzio]

The subject of The Feast of Herod was widely interpreted in the history of art through a variety of artistic media (fig. I). During the Renaissance, the story narrated by the Gospels of Mark and Matthew translates into a representation recalling theatrical sketches (bozzetti), which are characterized by a space-time sequence of multiple events that coexist in a single scene. In the I5th century rendition by Filippo Lippi (| 406- | 469), a strong influence of the sacred representations can be observed, probably because of the painter's links with the Carmelite order [Holmes 1999], in whose monastery he grew up and was educated. The impact of the sacred representations on Lippi's painting can be traced in the way his works "give the impression of being 'staged', with the characters represented [...] showing great self-consciousness and a strong awareness of the spectator's presence and his external view" [Holmes, 1999, p. 167]. As the vice-director of the Department of Cultural Heritage of the Duomo di Prato, Claudio Cerretelli, also points out, Fra Filippo's style is characterized

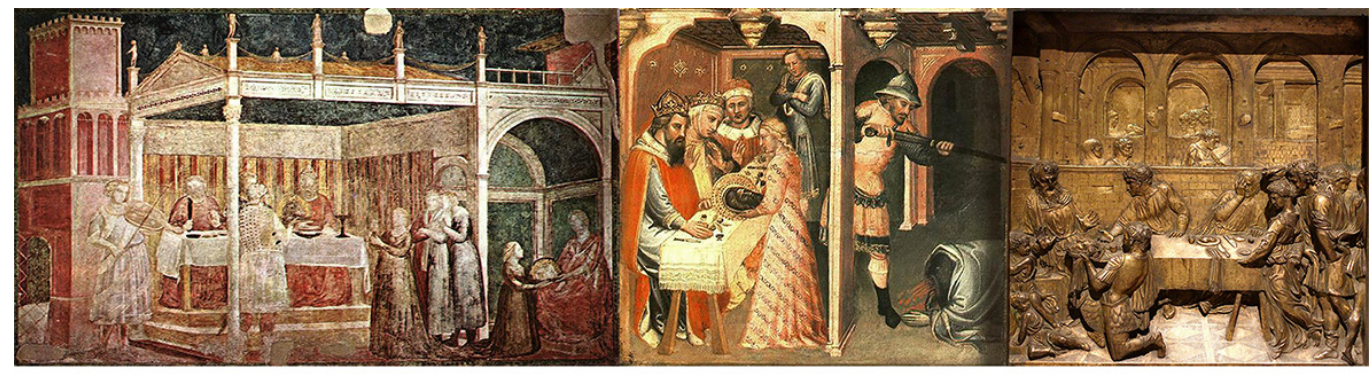

Fig. I. From left to right, from top to bottom Giotto, The Feast of Herod, 1320-1325, fresco secco, Basilica di Santa Croce, Cappella Peruzzi,
Firenze; Spinello Aretino, The Feast of Herod,

1385, tempera on panel, Szépmûvészeti Múzeum, Budapest; Donatello, The Feast of Herod, 1423-27, bronze relief, Battistero di Siena; Masolino da Panicale, The Feast of Herod, I435, fresco Battistero di Castiglione Battistero di Castiglione Olona; Benozzo Gozzol The Feast of Herod and the Beheading of Saint John the Baptist, | $46 \mid$ 1462, tempera on pane, National Gallery of Art, Washington; Domenico Ghirlandaio, The Feast of Herod, I 485-1490, fresco, Cappella Tornabuon Santa Maria Novell Firenze; Peter Paul Rubens, The Feast of Herod, ca. 163538 , oil on canvas, National Galleries of Scotland, Edimburgo.
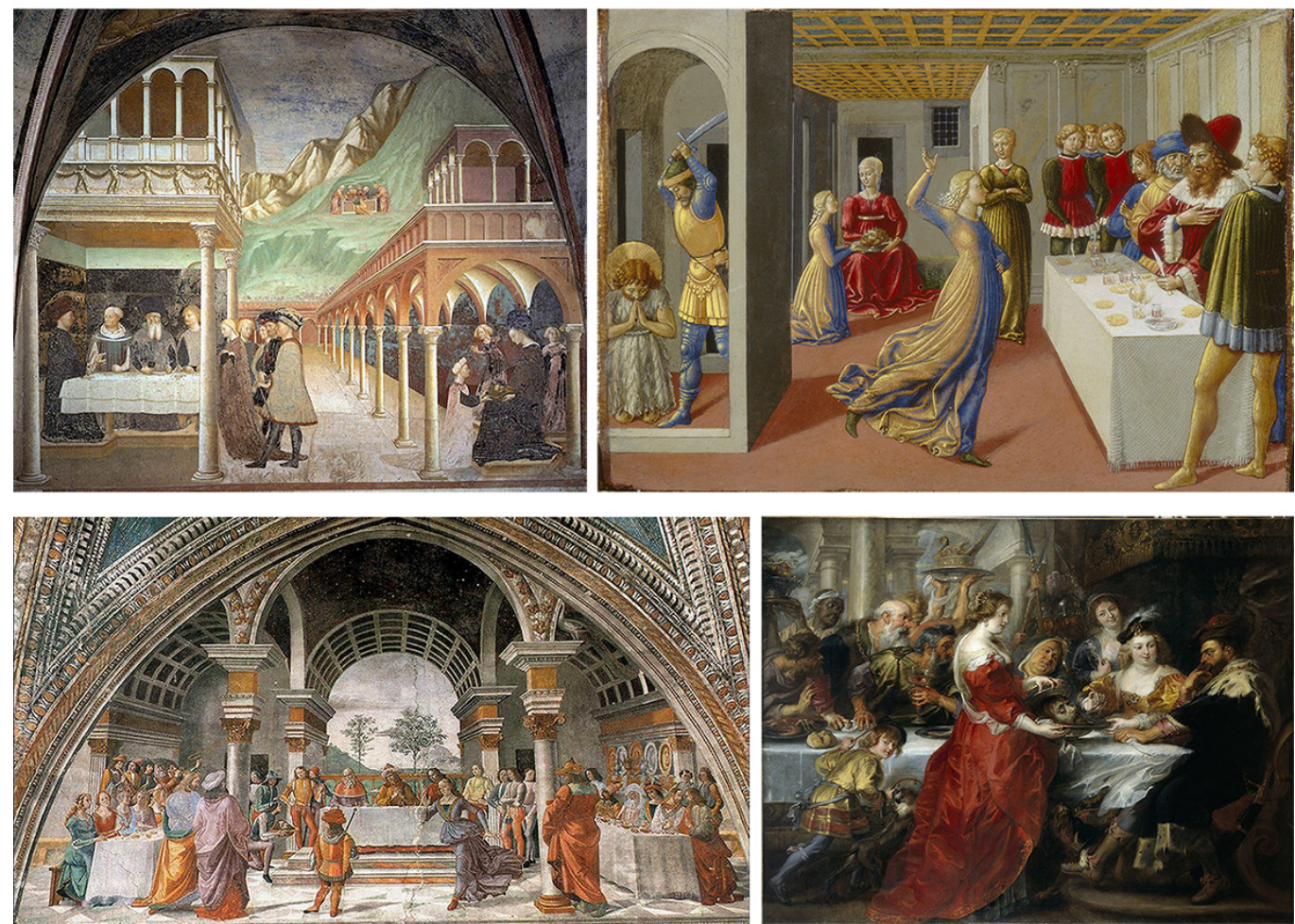
by [...] a skilled narrative vein, that actualizes and makes the complex sacred stories comprehensible, which are orchestrated as a big theatrical performance" [Cerretelli 20 I8]. The Feast of Herod (fig. 2) belongs to the Prato's well-known cycle of frescoes with the Stories of Saint Stefan and Saint John the Baptist, which, according to Vasari, is considered "the greatest of all his things" [Vasari 2016, p. 4I I]. It was made by Lippi and his collaborators between I 452 and I465, with long breaks due to the painter's complex romantic affairs and several other commitments. The Feast of Herod embodies the pinnacle of the complex journey undertaken by the artist in Prato and is rightly considered the last scene painted, therefore "it is the only one whose temporal location is certain, that is between summer and winter of I 465, just over a year before he definitively left for Spoleto" [Lapi Ballerini 20 I4, p. 26].

Fig. 2. Filippo Lippi, The Feast of Herod, from the cycle of frescoes with Stories of Saint Stephen and Saint John the Baptist | 452- | 465, fresco, 450 x $880 \mathrm{~cm}$. Prato, Duomo (Cappella Magriore) Photo Credit: Fototeca Ufficio Beni Cutturali Diocesi di Prato.

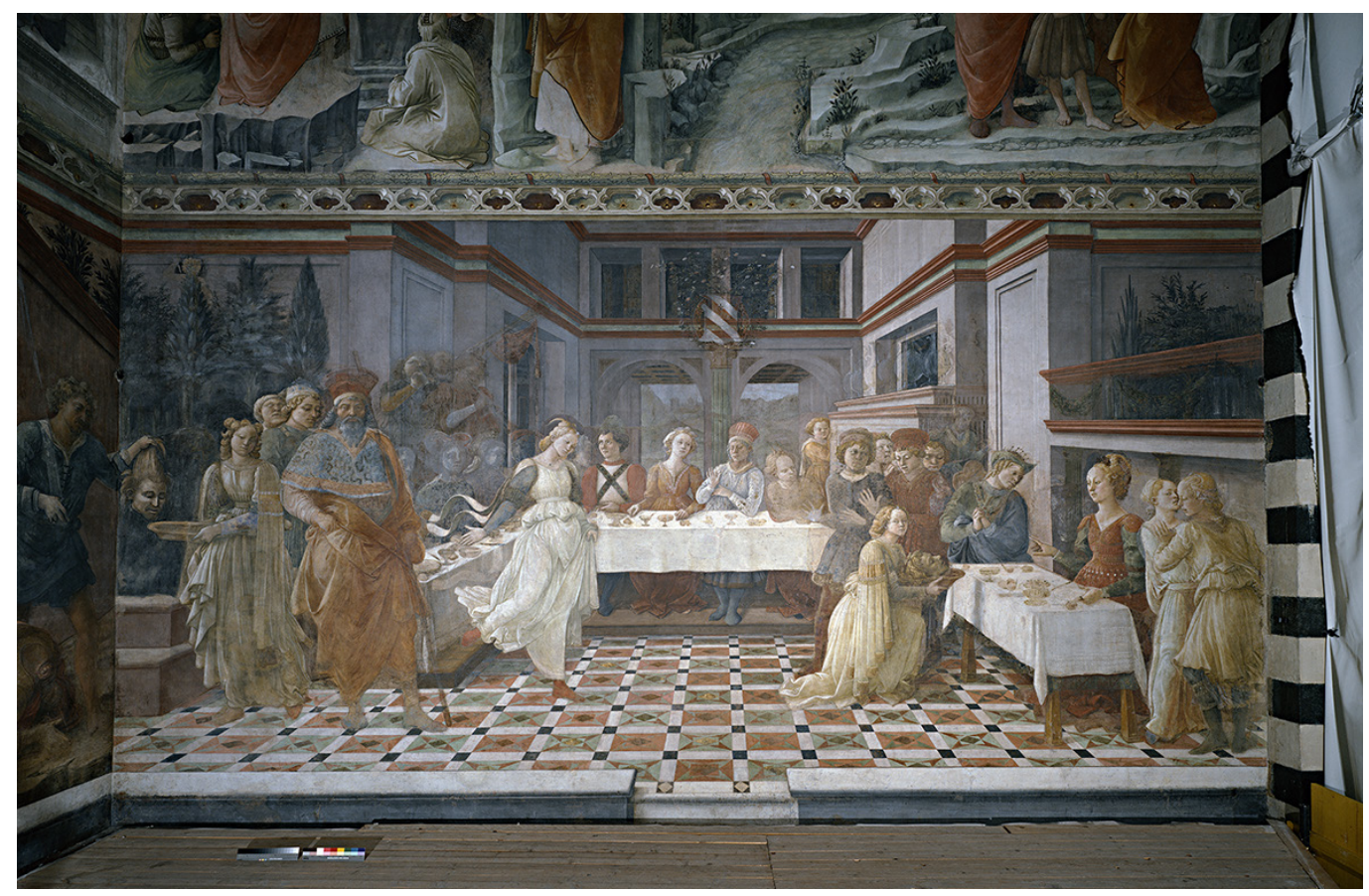

\section{Iconography}

The artist stages a sumptuous feast set in an elegant Renaissance-style building, populated by several guests in contemporary costumes. The subject is just a pretext to imagine and describe in details the wide space in which the events take place; indeed, the drama of the tragic story is barely perceptible, almost relegated on the fringes of the scene. Herodias, dressed in elegant and aristocratic garments, looks cold and emotionless; her attitude contrasts with the wide range of expressions of surprise and disgust displayed by the guests attending the macabre event. The absolute protagonist is the sensual and delicate figure of Salomé (probably Lucrezia Bruti, Lippi's loved woman) defined by a sinuous, fine and soft contour line. The maiden appears three times and with three different faces, wrapped in a pure-white light dress with fluttering veils. As A. Chrzanowska states, "in this scene the encounter between innovation and tradition typical of Lippi's narrative is visible more than ever. Here, more than in the rest of the cycle, the contrast between a coherent perspective space and the continuous narrative is amplified" [Chrzanowska 2016, p. 205]. In the fresco, the three most important moments of the biblical episode are depicted: The Beheading of Saint John the Baptist on the far left (the executioner and the beheaded corpse of the Baptist are located on the wall adjacent to the fresco); The Dance of Salomé in the middle section; Salomé presenting the head to Herodias on the right side (fig. 3).The events narrated, 
despite being totally distinct, are unified in a homogeneous space thanks to the rigorous perspective layout traced by the carved marble tiles of the floor, by the tables covered by white tablecloths and by the receding of the side walls, whose main vanishing point is placed on the vertical axis of symmetry (fig. 4). The reading order of the three different moments is non-linear: the narration starts from the space circumscribed by the tables in the middle (Salomé's dance), it then moves towards the left (the beheading) and finally ends on the

Fig. 3. The three main moments of the narration, highlighted in chronological order. From top to the Beheading of Salome, the Baptist and Salomé presenting the head to Herodias.

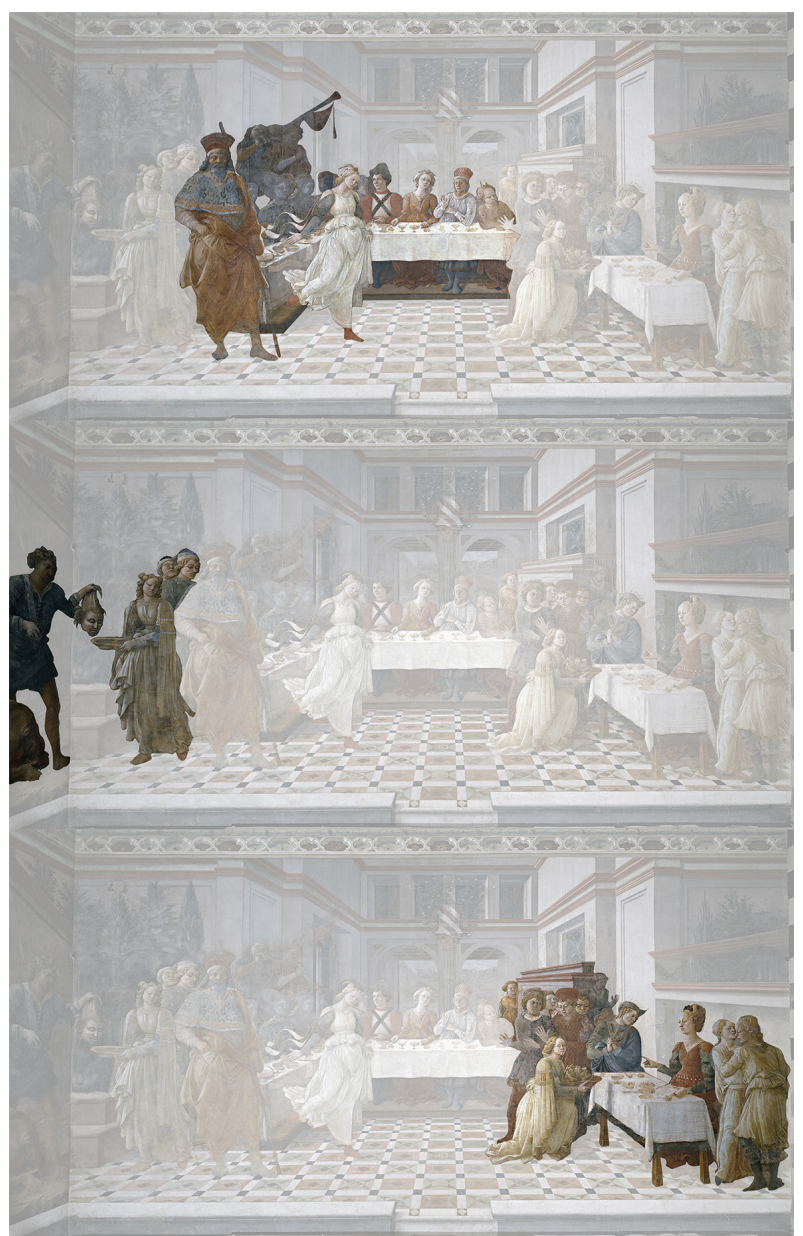

right (the presentation of the head to Herodias). Salomé 'moves' on different perspective planes but with an almost linear trend (fig. 5). It seems like Salomé of the central scene is tracing a time line marked by the rhythm of her movements, as if she danced from left to right; in this way, the three phases of the narration are related to each other in a non-chronological order. Nevertheless, the scene on the left is quite isolated compared to the others, as if the painter wanted to give proper solemnity and intimacy to the most tragic moment of the story (the Beheading). Despite the coexistence of three different moments in the same scene, Lippi manages to preserve the readability of the sequence thanks to the exchange of glances between characters which interact -more or less directly- with the observer, guiding him in the narration. A couple of examples can be traced in the figure of Salomé down on her knees, turning her gaze to the spectator or in the last guest sitting at the far-right of the central table, who acknowledges the subsequent scene taking place next to him. The characters themselves, located on different perspective planes, are the main elements used by the painter to mark and underline the separation between the scenes (e.g. the mace bearer with the headgear and the beard in the foreground and the group of guests around the 


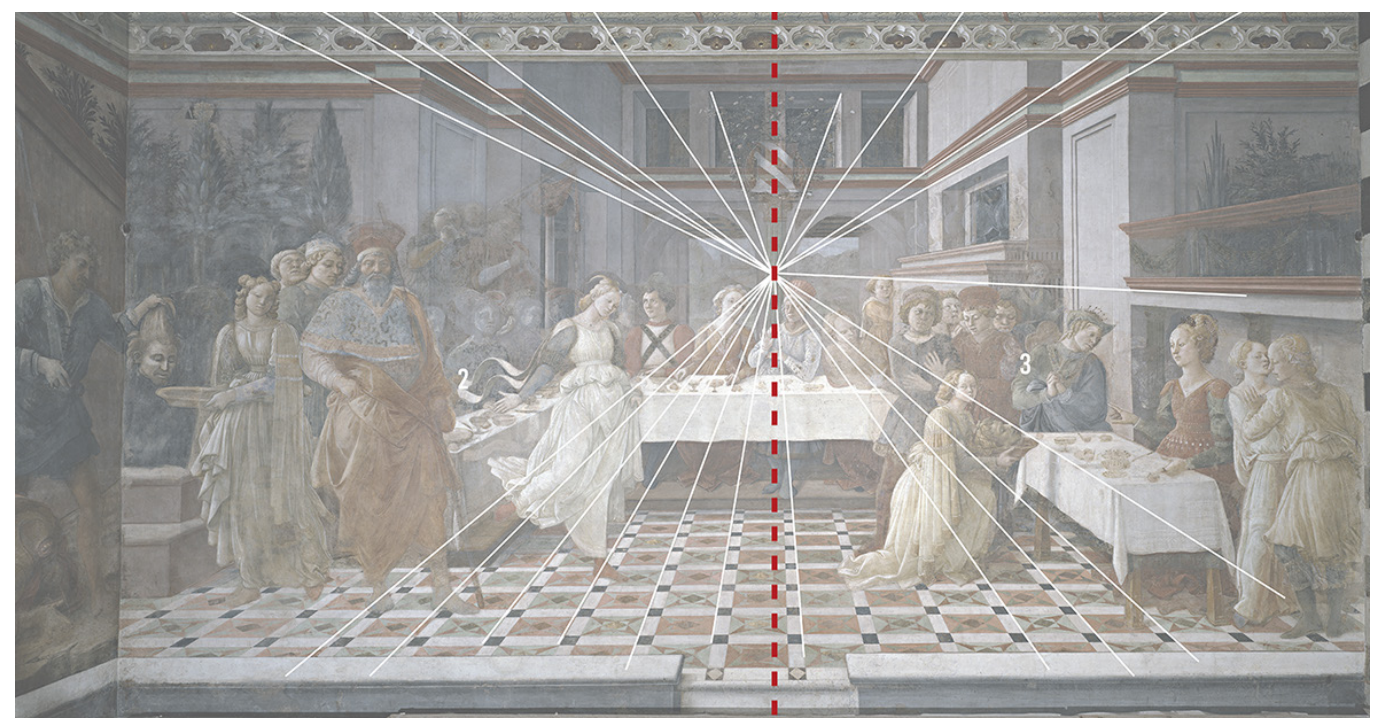

Fig. 5. The different

perspective planes of the scene with Salomé's ideal movement.
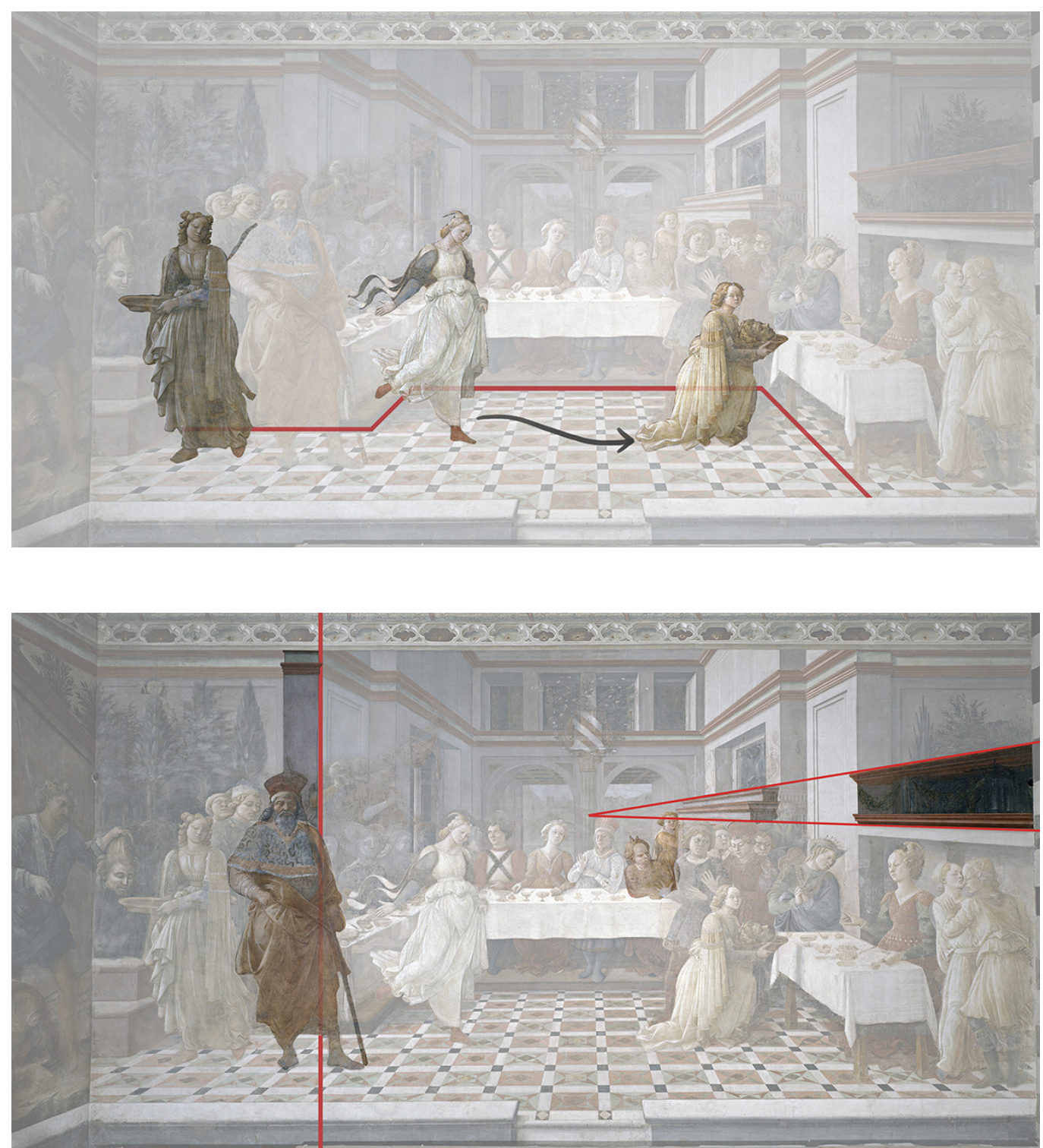
table on the right). Lippi's effort of unifying the spatial arrangement of the scenes is exactly what turns the fresco into a performance, making it possible to "bring the figures to life in the spectator's imagination" [Chrzanowska 2016, p. 207]. However, not only the characters separate the different moments of the narration: a careful analysis of the architectural layout shows that the two side scenes are closer to the spectator compared to the one in the center, which is slightly set back. Also, the presence of a pilaster on the left wall along with the massive out-of-scale figure of the mace bearer, defines the limit of the scene in which the head of the Baptist is presented to Salomé. Finally, on the right side, a horizontal frame breaks the symmetry of the architecture, framing the third and last scene (fig. 6).
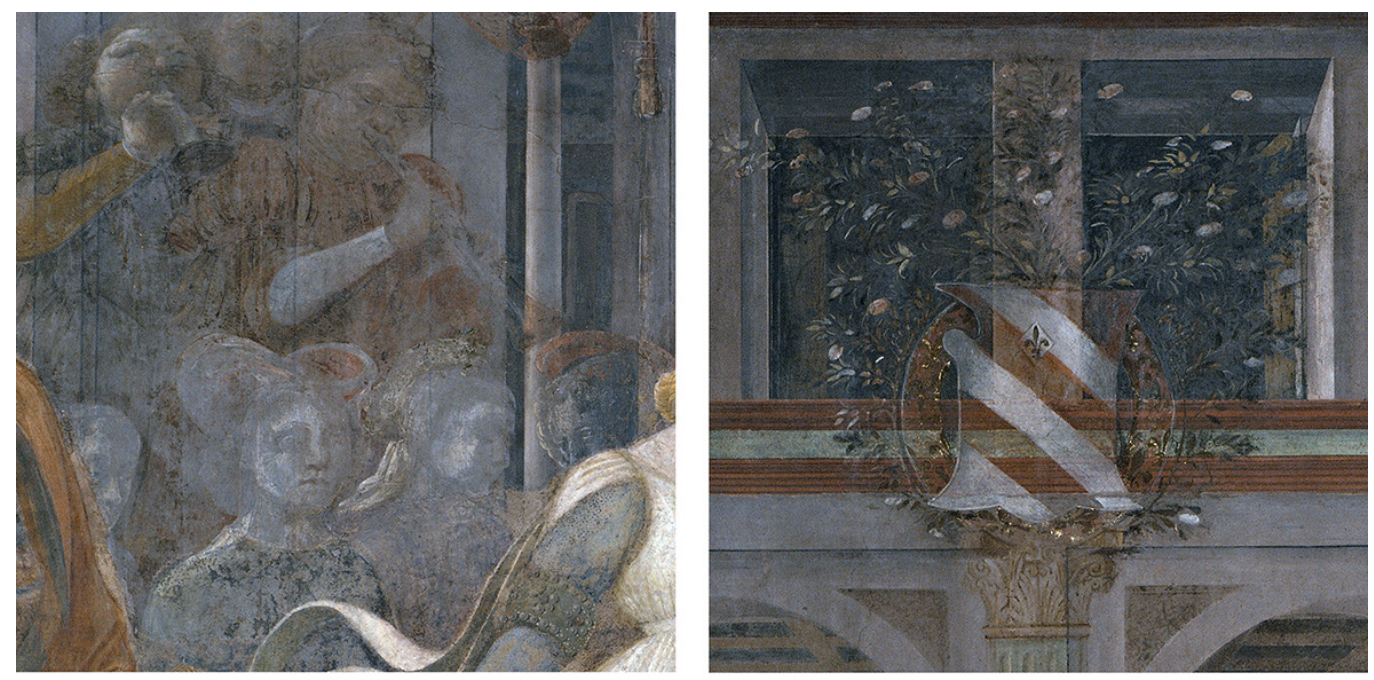

Fig. 7. Characters, details and objects appearing as 'evanescent ghosts' as they have been added later ' a secco' and consequent
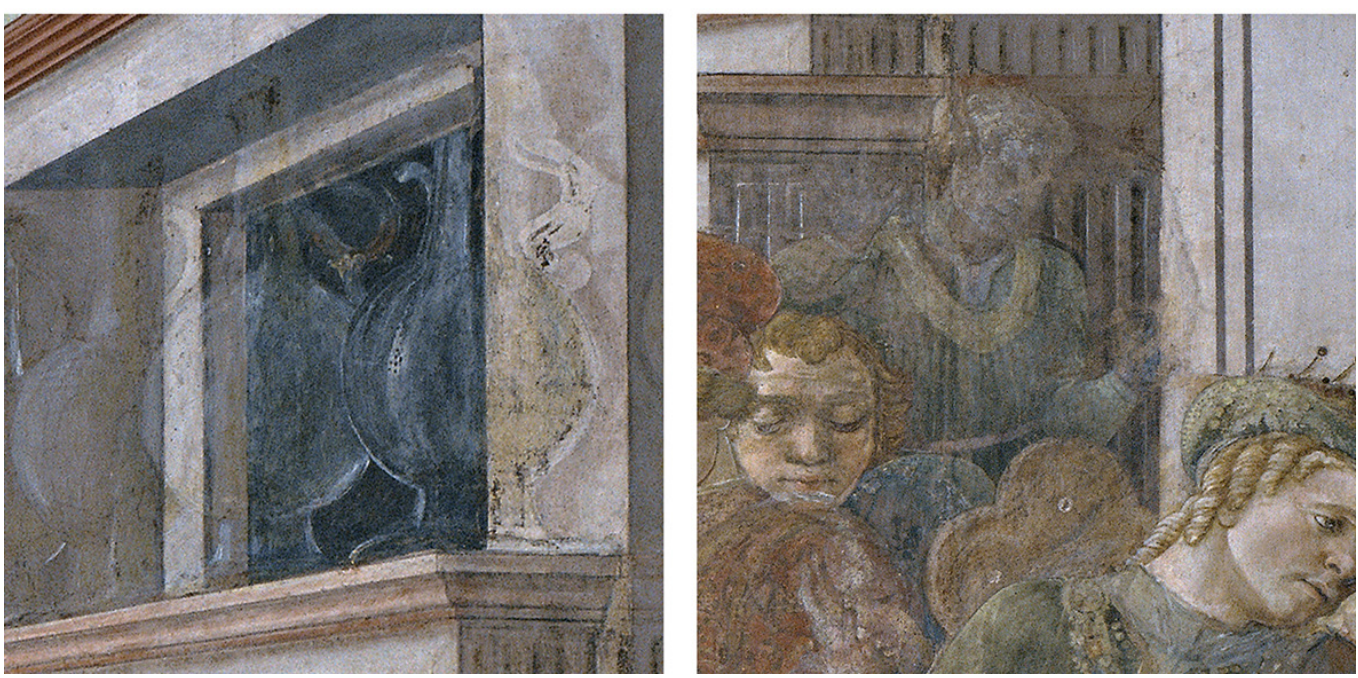

\section{The perspective restitution of the painted space}

The one-point perspective restitution of Filippo Lippi's painted space has been carried out through the reversed procedure of linear perspective. First of all, it was necessary to identify the internal orientation of the projective reference, starting from the main point $\mathrm{V}_{\text {, }}$, the orthogonal projection on the plane of the fresco of the observer's viewpoint $(V)$. The horizon line has been identified as the locus of the points of intersection of the horizontal lines perpendicular to the painting. Since we are dealing with a vertical one-point perspective, $V_{0}$ belongs to the horizon line and it is the center of the 90-degree circle of view whose radius 
is $\mathrm{V}_{0} \mathrm{~V}$ *, where $\mathrm{V}$ * coincides with the viewpoint $\mathrm{V}$ that is reversed on the painting [Pagliano 2005, p. 42]. The fictitious ground line $f$ coincides with the lower limit of the painting, as usual in the case of restitutions of vertical one-point perspective painted architectures. Despite the layout being apparently coherent and regular, the redrawing of the perspective lines of the floor unmasks a failed convergence towards a single pair of points of the diagonals of the floor quadrangles separated by white bands, which the painter clearly suggests being square shaped. Therefore, the tiles (supposedly square shaped) of the second and third lines (parallel to the viewing plane) towards the observer were chosen as a reference to identify points $D_{1}$ and $D_{2}$. An intersection points cloud is obtained by extending the diagonals of the tiles until the horizon line. Such intersection points are slightly different from each other because of some unavoidable inaccuracies in the realization of the painting, especially considering the huge scale of the fresco. Distance points $D_{1}$ and $D_{2}$ are consequently fixed in the center of the area resulting from the aforementioned intersections on the horizon line. Once the projective reference of the painted image was identified, the geometrical analysis and the graphic restitution of plane and sections of the painted space was subsequently carried out by means of the overturning method applied to vertical one-point perspective.

Fig. 8. From top to bottom: a) The correct perspective layout (white lines) and the errors in the representation of architectural element opening in the right wall (red lines);

b) The correct shape of the table in perspective (red lines).

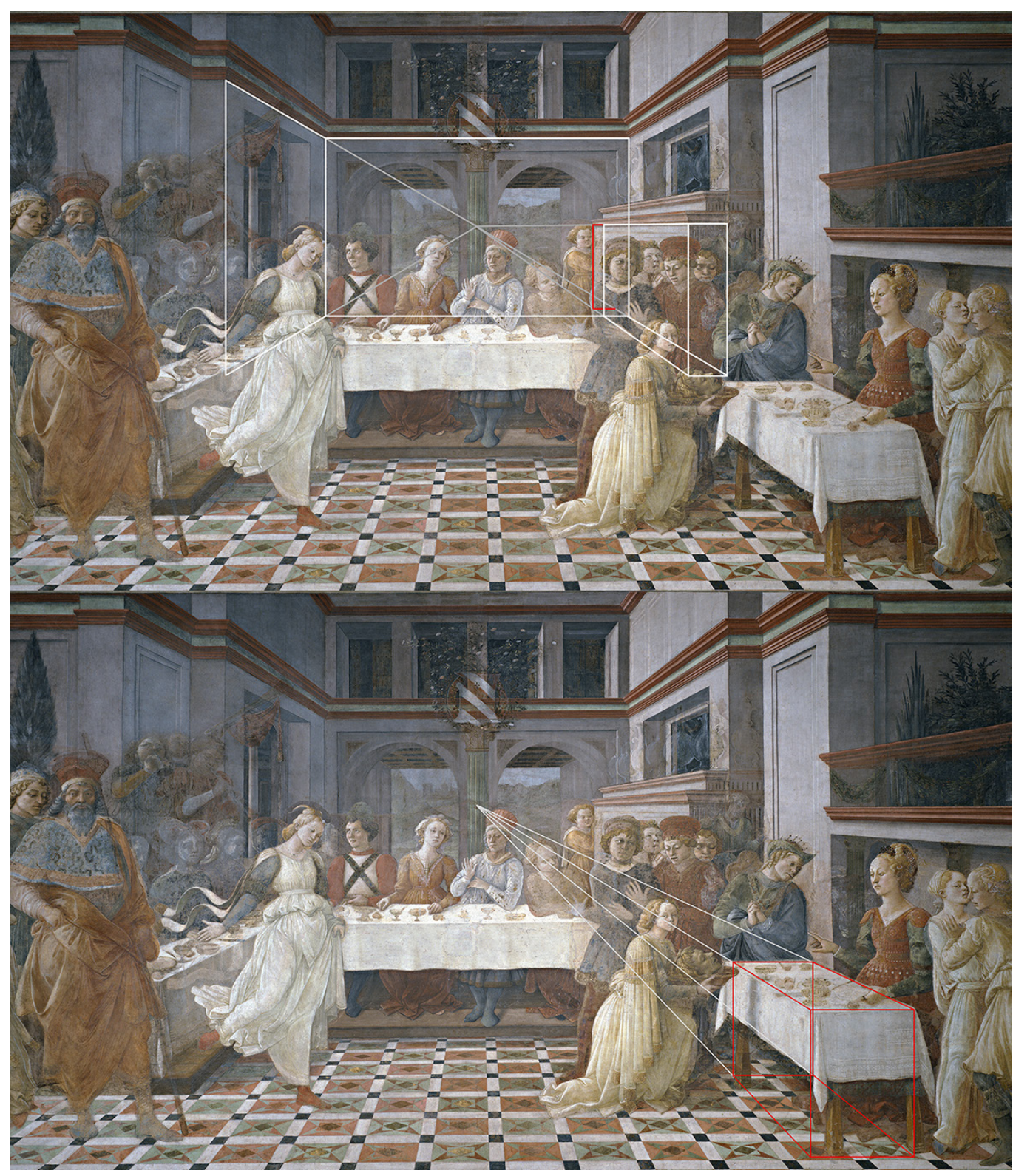


The geometric analysis shows that Lippi's space is characterized by a substantially regular layout since all horizontal lines share the same vanishing point, besides some isolated exceptions. It is clear that the painter wanted to stage a space based on a precise architectural design, characterized by balance and proportion as well as by a strong symmetry along the vertical axis, which passes through $\mathrm{V}_{0}$, that is the trace of the vanishing point of the main viewing plane. The restituted plan confirms the hypothesis that Lippi aimed at obtaining a strongly symmetric space: indeed, despite the inaccuracies related to the realization of the painting, the staged architecture is almost perfectly symmetrical with respect to its longitudinal axis. For instance, the side openings in the walls are specular and of the same length; also, the round arches and the windows in the back also appear to be symmetric in relation to the central pilaster where, not by chance, the vanishing point is located. Nevertheless, Lippi's painted space is not without irregularities; aside from minor imperfections due to the brushstrokes and the difficulty of execution on a large format, it is possible to observe a number of deviations from the rules intentionally made by the artist to meet aesthetic needs: the painter's main priority is indeed to improve the visual relationship between architecture and human figures. Hence, Lippi sacrifices the formal rigor of the painted architecture in favor of the overall view. Furthermore, it is evident that some characters and decorative details were added at a later time 'a secco' [Gittins, Vedovello 20I4, p. 54] [I]: in fact, some parts underwent a massive and faster deterioration compared to the frescoed ones. For example, the group of characters set against the left wall of the scene behind the table look like faded and evanescent ghosts, which contrasts with the strong opacity of the other human figures in the painting [Lapi Ballerini 20I4, p. 26 ] [2].The same can be observed in the coat of arms of the Ceppo Nuovo by Francesco Marco Datini surrounded by lilies, the symbol of the City of Prato [Borsook 1975, p. 57] (fig. 7).

The perspective analysis also revealed that the architectural element crowned by moldings located in front of the opening on the right wall (in which it seems to be incorporated) appears to be set back compared to its real position according to the perspective's coordinates and consistent with a rigorous application of the perspective method (fig. 8a). The architectural element isn't correctly represented by Lippi and it indeed intersects the back wall; therefore, it shouldn't be possible to see it. Even the table behind which Herodias is sitting isn't a fully coherent perspectival representation: by tracing its contour, we find out that its geometry can't be ascribed to the parallelepiped in which it should be inscribed. The perspective restitution shows that Lippi's painted space is accurately designed for what concerns the area in front of the long spread table, dominated by the colored chessboard

Fig. 9. Geometric pattern which characterizes the square tiles of the floor (two color variants), (graphic elaboration by the author).
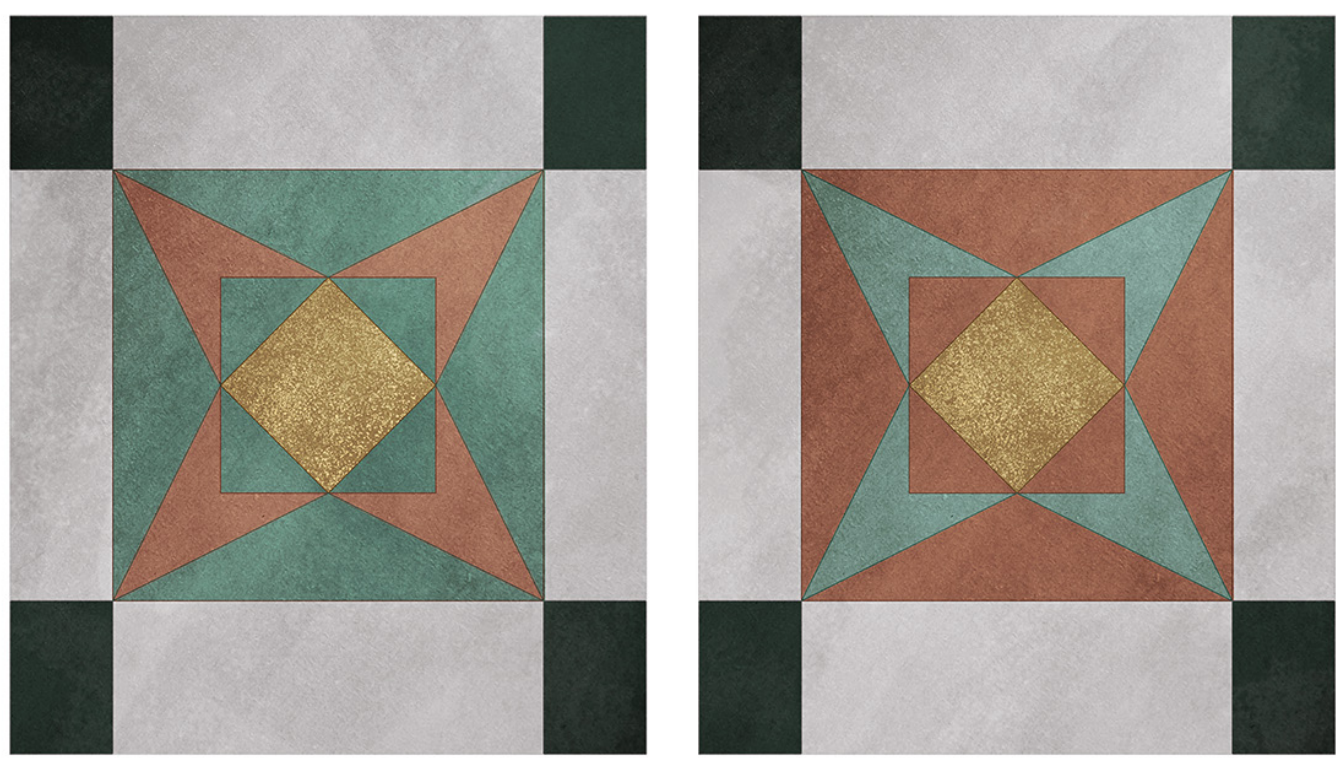
resulting from the patterned floor where the main character, Salomé, is moving: this is the space where the protagonist's dancing and stage movements take place. Such space and the elements in it show plausible proportions and dimensions, as opposed to what happens starting from the table section parallel to the painting plane, that was found to be twice deeper than the side table and consequently produces an implausible representation of the diners. The latter are sitting on a bench, as we can intermittently see through the legs and clothes of the characters. Nevertheless, given the significant depth of the table, their position is anatomically impossible. However, the aim of Lippi's decision to make the table so significantly depth is to allow the observer to see the objects on the horizontal plane. As we move towards the back of the painted architecture, the space obtained through the perspective restitution becomes considerably longer, especially beyond the two round arches of the wall at the back of the feast. In the rectangular opening on the left wall it is possible to see a pair of arches sustained by a central column. Although these seem to be round arches, they are actually segmental arches and the wall containing them isn't thick enough to house the central column. The banner hanging from the trumpet played

Fig. 10. From left to right from top to bottom: Filippo Lippi, I funerali di Santo Stefono, ca. 1460 , cycle of frescoes with the Stories of Saint Stephen and Saint ohn the Baptist, Duomo, Prato; Filippo Lippi, Circoncisione, ca. I 460- | 465 panel, Chiesa dello Spirito Santo, Prato; Filippo Lippi, Santo Stefano è nato e sostituito con un altro bambino (particular), ca 460 ciclo di affreschi I460, ciclo di affresch Stephen and Saint John the Baptist, Duomo, Prato.

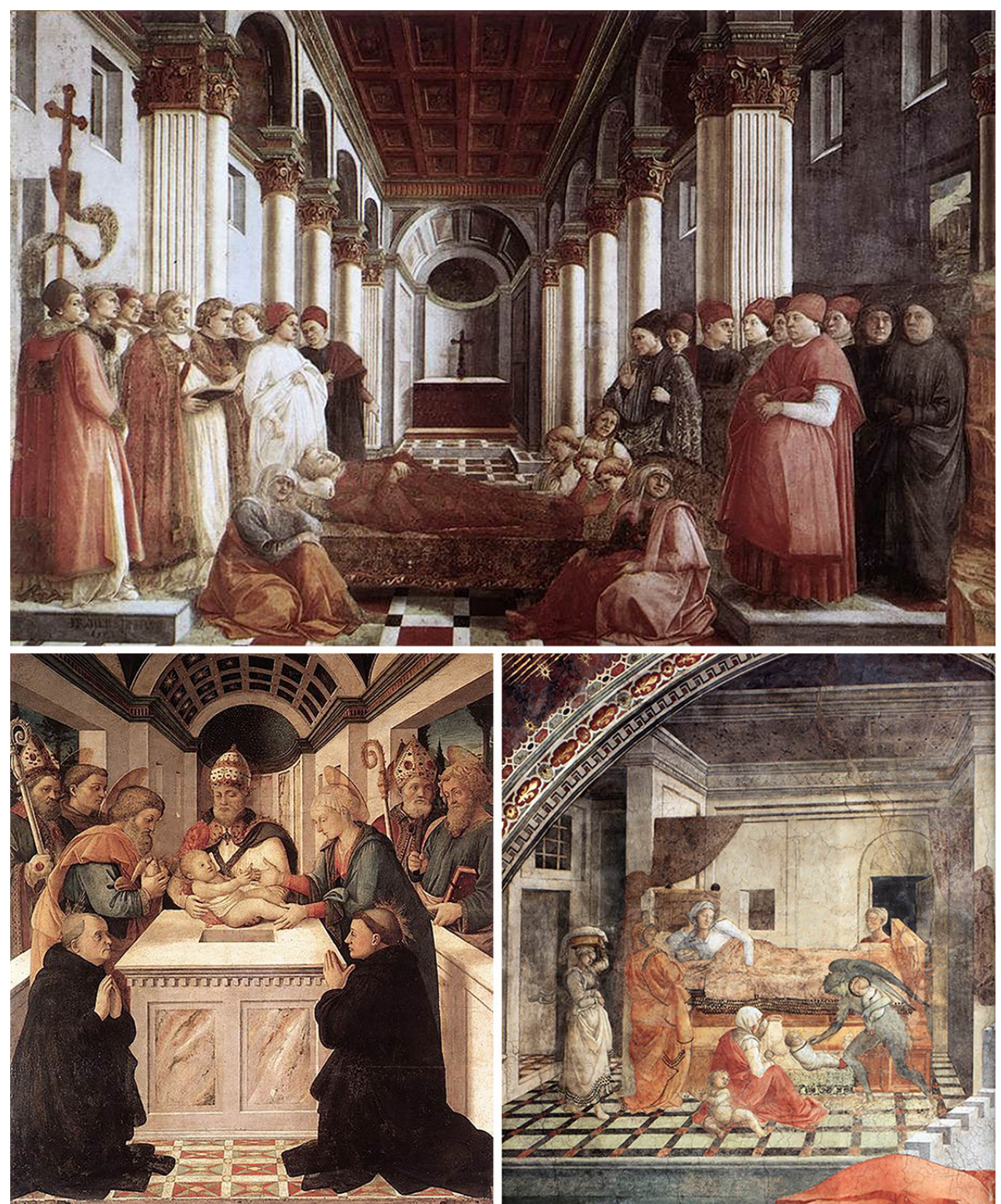


by the musician was probably superimposed, at a later time, exactly on the capital of the column corresponding to the impost of the arches, in order to conceal the painter's uncertainties. The coffered ceiling that can be seen beyond the arches is made of rectangular elements separated by considerably wide bands. Lippi intentionally obtains a slowed perspective effect so that the bands dividing the ceiling coffers are clearly visible as well as not excessively reduced along the depth of the space. In the philological restitution, the consistency of the spatial unity was restored by operating a 'correction' of the image to make it perfectly adherent to the perspective's coordinate system. In particular, the restitution of the geometrical floor confirms the aforementioned incongruences, showing that the squares are not all perfectly square-shaped and they tend to gradually flatten towards the back, as in the case of the horizontal bands that divides them. On the other hand, the vertical divisions are more regular and the differences in extent between each bands are minimal. In order to make the architectural layout of the obtained perspective spaces coherent, in the philological restitution the quarters of the floor were made perfectly square-shaped with the bands dividing them having the same depth, leaving the number of lines parallel and per-

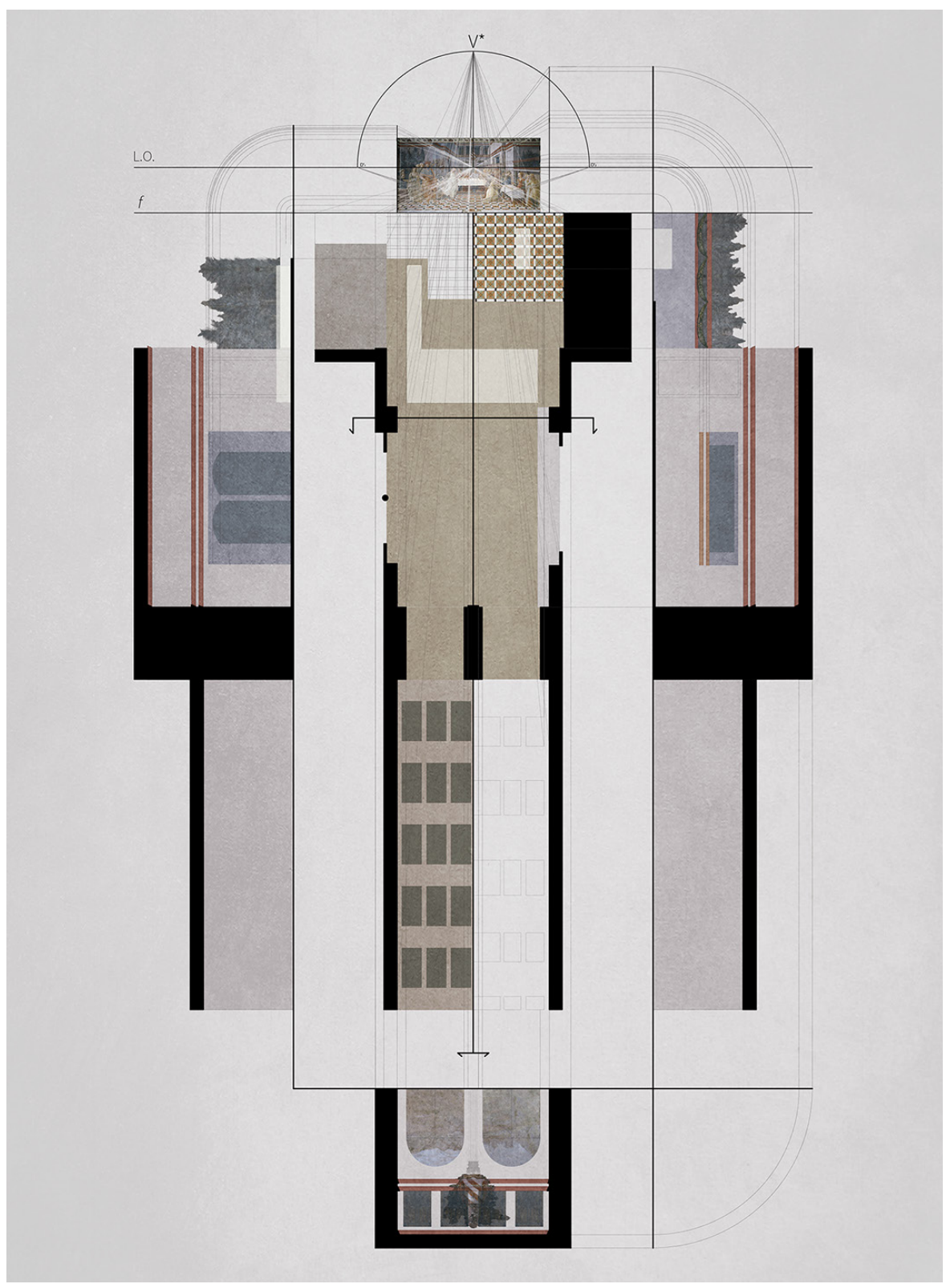


pendicular to the painting unchanged. The geometric pattern of the quarters appears to be made of a central square (originally made of golden wax), an equilateral rhombus inscribed in it and four isosceles triangles whose bases coincide with each side of the rhombus and whose vertexes correspond to the vertexes of the quarter (fig. 9). Similarly, the coffered ceiling located beyond the round arches was regularized, respecting the proportions of the bands dividing horizontally the rectangular elements and leaving the number of lines parallel and perpendicular to the painting unaltered. The hypotheses concerning the square-shaped floor and the rectangular-shaped wooden coffered ceiling were formulated also by analyzing other paintings by Lippi, in which similar features can be observed (fig. I0). Hence, the layout becomes regular and coherent, while respecting the artist's intentions. The digital three-dimensional model obtained from the orthogonal projections of plans and section of Lippi's painted space can be 3D printed and placed next to the original fresco in order to make the latter accessible by a visually impaired audience and to allow all visitors to better understand the staged space.
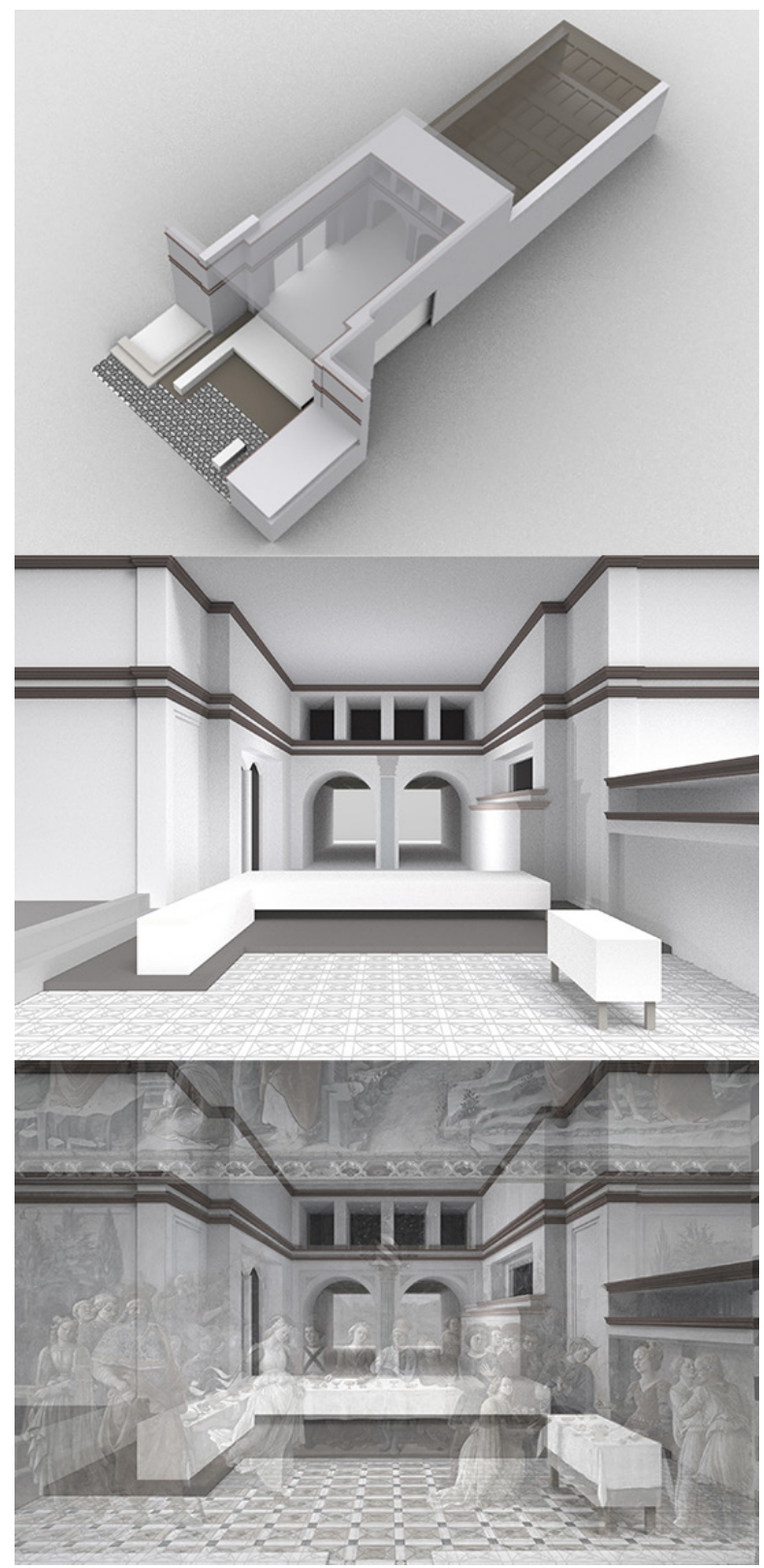


\section{Conclusion}

The perspective restitution operations highlighted the choices made by Filippo Lippi when planning the space designed to host the narrated events. Such space is characterized by a global perceptual harmony and a substantial symmetry, except for when the architecture is required to meet narrative needs. Therefore, perspective restitution proved to be other than an automatic translation of a space painted in perspective into its plans and sections: it is, instead, a true interpretative act. The critical action of the philological restitution is essential when dealing with painted spaces produced by an artist's imagination. An artist who, acting between rule and derogation, often sets perceptive and aesthetical needs before the strict application of the geometric-scientific method. The interpretation of the painted image holds harmoniously together descriptive geometry, history of art, digital representation and drawing competences. This results in convincing and suggestive iconographic interpretations.

\section{Notes}

[I] As Gittins e Vedovello state, "in The Feast of Herod there is a freer and more extensive use of the 'a secco' technique. In the middle area, for instance, the "giornate" follow the architecture and the decision to add a group of guests (it is not known if it was already planned or if he painted them later to better balance the composition) was carried out without using new fresh plaster; instead, such figures were simply painted 'a secco'"' [Gittins, Vedovello 20 I 4, p. 54].

[2] As noted by Isabella Lapi Ballerini," I 3 figures - which today look evanescent if not almost invisbile - were added 'a secco' to crowd the composition [...]; added, not 'deleted' " [Lapi Ballerini 20 I4, p. 26].

\section{References}

Borsook Eve (1975). Fra Filippo Lippi and the Murals for Prato Cathedral. In Mitteilungen des Kunsthistorischen Institutes in Florenz, 19, pp. I- |48, I/1975.

Cerretelli Claudio (2018). Personaggi importani: Filippo Lippi: <hhttp://www2.po-net.prato.it/artestoria/personalita/filippolippi/pagina87.html>.

Chrzanowska Agata (2016). Narrative Fresco and Ritual: Filippo Lippi, Domenico Ghirlandaio and Performative Properties of the Religious Art in Quattrocento Florence. Durham: Durham University

Gittins Mark, Vedovello Sabrina (20 4). Problemi operativi e risultati del recente restauro. In Benassai Paolo, Ciatti Marco, De Marchi Andrea et al. (a cura di). Officina Pratese: tecnica, stile, storia. Firenze: Edifir Edizioni Firenze, pp. 53-62.

Holmes Megan (1999). Fra Filippo Lippi. The Carmelite Painter. New Haven:Yale University Press.

Kubovy Michael (1992). La freccia nell'occhio. Psicologia della prospettiva e arte rinascimentale. Padova: Franco Muzzio Editore.

Lapi Ballerini Isabella (20|4). II restauro degli affreschi di Filippo Lippi a Prato fra metodo e riflessione critica. In Benassai Paolo, Ciatti Marco, De Marchi Andrea et al. (a cura di). Officina Pratese: tecnica, stile, storia. Firenze: Edifir Edizioni Firenze, 19 -30.

Pagliano Alessandra (a cura di). (2005). La scena svelata: architettura, prospettiva e spazio scenico. Padova: II Poligrafo.

Paolucci Antonio (2007). Filippo Lippi. Firenze: Giunti.

Ruda Jeffrey (1993). Fra Filippo Lippi. Life and Work with a Complete Catalogue. London: Phaidon.

Vasari Giorgio (20 I6). Le vite dei più eccellenti pittori, scultori e architetti. Roma: Newton Compton Editori. (Ed originale I550).

Author

Barbara Ansaldi, Università degli Studi di Napoli “Federico II", barbara.ansaldi@unina.it

To cite this chapter: Ansaldi Barbara (2020). Dentro II Convito di Erode di Filippo Lippi. Analisi geometrica e restituzione prospettica dello spazio dipinto/Inside The Feast of Herod by Filippo Lippi. Geometric analysis and perspective restitution of the painted space. In Arena A., Arena M., Brandolino R.G., Colistra D., Ginex G., Mediati D., Nucifora S., Raffa P. (a cura di). Connettere. Un disegno per annodare e tessere. Atti del $42^{\circ}$ Convegno Internazionale dei Docenti delle Discipline della Rappresentazione/Connecting. Drawing for weaving relationships. Proceedings of the 42 th International Conference of Representation Disciplines Teachers. Milano: FrancoAngeli, pp. 2907-2930. 